Anionic N-heterocyclic carbenes derived from sydnone imines such as molsidomine. Trapping reactions with selenium, palladium, and gold

Freese, Tyll

2017-09-07

Freese , T , Lücke , A-L, Schmidt, C A S , Polamo, M , Nieger , M , Namyslo , J C \& Schmidt , A 2017 , ' Anionic N-heterocyclic carbenes derived from sydnone imines such as molsidomine. Trapping reactions with selenium, palladium, and gold ' , Tetrahedron, vol. 73 , no. 36 , pp. 5350-5357 . https://doi.org/10.1016/j.tet.2017.07.032

http://hdl.handle.net/10138/309235

https://doi.org/10.1016/j.tet.2017.07.032

cc_by_nc_nd

acceptedVersion

Downloaded from Helda, University of Helsinki institutional repository.

This is an electronic reprint of the original article.

This reprint may differ from the original in pagination and typographic detail.

Please cite the original version. 


\section{Graphical Abstract}

Anionic N-heterocyclic carbenes derived

Leave this area blank for abstract info.

from sydnone imines such as molsidomine.

Trapping reactions with selenium,

palladium, and gold.

Tyll Freese, ${ }^{a}$ Ana-Luiza Lücke, ${ }^{a}$ Catharina A. S. Schmidt, ${ }^{a}$ Mika Polamo, ${ }^{b}$ Martin Nieger, ${ }^{b}$ Jan C. Namyslo and Andreas Schmidt*a

${ }^{a}$ Clausthal University of Technology, Institute of Organic Chemistry, Leibnizstrasse 6, D-38678 ClausthalZellerfeld, Germany. Phone: +49-5323-72-3861; Email: schmidt@ioc.tu-clausthal.de

${ }^{b}$ University of Helsinki, Department of Chemistry, Laboratory of Inorganic Chemistry, P.O. Box 55, FIN-00014 University of Helsinki, Finland.
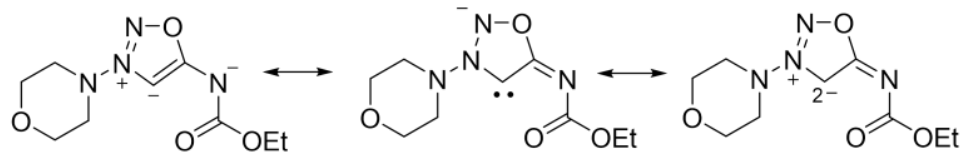


\title{
Anionic N-heterocyclic carbenes derived from sydnone imines such as molsidomine. Trapping reactions with selenium, palladium, and gold.
}

\author{
Tyll Freese, ${ }^{\mathrm{a}}$ Ana-Luiza Lücke, ${ }^{\mathrm{a}}$ Catharina A. S. Schmidt, ${ }^{\mathrm{a}}$ Mika Polamo, ${ }^{\mathrm{b}}$ Martin Nieger, ${ }^{\mathrm{b}}$ Jan C. \\ Namyslo a and Andreas Schmidt*a \\ ${ }^{a}$ Clausthal University of Technology, Institute of Organic Chemistry, Leibnizstrasse 6, D-38678 Clausthal-Zellerfeld, Germany. Phone: +49-5323-72-3861; \\ Email: schmidt@ioc.tu-clausthal.de \\ ${ }^{b}$ University of Helsinki, Department of Chemistry, Laboratory of Inorganic Chemistry, P.O. Box 55, FIN-00014 University of Helsinki, Finland.
}

\section{ARTICLE INFO}

Article history:

Received

Received in revised form

Accepted

Available online

\section{Keywords:}

Mesoionic compound

Carbon(0)

Carbene

Suzuki-Miyaura reactions

Sonogashira-Hagihara reactions

\section{ABSTRACT}

The sydnone imines Molsidomine and 5-(benzoylimino)-3-(2-methoxyphenyl)-1,2,3oxadiazolium-2-ide gave anionic $\mathrm{N}$-heterocyclic carbenes on deprotonation at $\mathrm{C} 4$ which were trapped as methylated selenium adducts, gold complexes (X-ray analysis) as well as palladium complexes (X-ray analysis). The ${ }^{13} \mathrm{C}$ NMR resonance frequencies of the carbene carbon atom are extremely shifted upfield and appear at $\delta=142.1 \mathrm{ppm}$ (Molsidomine carbene) and $\delta=159.8 \mathrm{ppm}$ (sydnone imine carbene). The Pd complexes were applied as catalysts in Suzuki-Miyaura and Sonogashira-Hagihara cross-coupling reactions.

2017 Elsevier Ltd. All rights reserved.

\section{Introduction}

Currently, the design and the syntheses of anionic $\mathrm{N}$ heterocyclic carbenes ${ }^{1}$ including ditopic carbanionic $\mathrm{N}$ heterocyclic carbenes ${ }^{2}$ and anionic dicarbenes ${ }^{3-5}$ constitute an important topic in structural, complex, synthetic and catalytic chemistry. To date, anionic NHCs have been generated by deprotonation of neutral N-heterocycles, ${ }^{6-10}$ by incorporation of anionic groups into the NHC backbone, ${ }^{11-15}$ or by reduction of an $\mathrm{NHC}$ in the presence of a metal. ${ }^{16-18}$ Consequently, several types of anionic N-heterocyclic carbenes have been prepared which can be differentiated i.a. by the $\pi$-electronic influence of the negatively charged partial structure on the carbene carbon atom. Some selected examples are presented in Scheme 1. In the anionic Nheterocyclic carbene 1 the carbene carbon atom of the imidazol-2ylidene ring is isolated by $\sigma$-bonds from the sulfonate group ( $c f$. 1I).$^{19}$ By contrast, the anionic carbenes $\mathbf{2}^{20}$ and $\mathbf{3}^{21-23}$ are examples of anionic $\mathrm{N}$-heterocyclic carbenes which are $\pi$-conjugated as they originate from conjugated mesomeric betaines. As shown by $\mathbf{2}_{\mathrm{I}}$ and $3 \mathbf{I}$, the negative charge is delocalized within the $\pi$-conjugated system which includes the carbene carbon atom. Consequently, the carbene carbon atom possesses coefficients of the highest occupied molecular orbitals (HOMO) which were calculated to be $\pi$-orbitals, respectively. In general $\pi$-electrons can be fed into the imidazol-2-ylidene moiety by substituents which are attached to $\mathrm{C} 4 / 5$ as in carbene 2 or to one of the nitrogen atoms as in carbene 3. Other examples of conjugated systems with related structures have been described as well. ${ }^{24-32}$

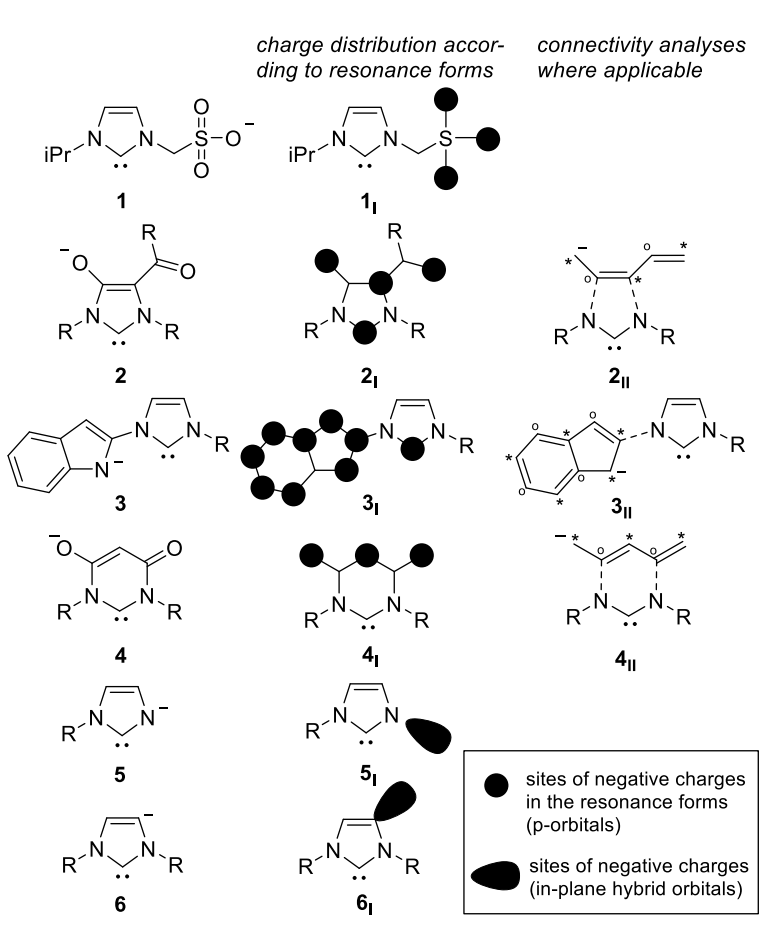

Scheme 1. Comparison of anionic N-heterocyclic carbenes 
Tetrahedron

The relationship between heterocyclic mesomeric betaines isoconjugate with hydrocarbon dianions and pairs of alternant hydrocarbon fragments has been studied by Ramsden. ${ }^{33-35}$ The interactions of alternant hydrocarbon fragments with pairs of associated $2 p$ heteroatoms (NR, O, S) is the base for an understanding of chemical and physical properties of mesomeric betaines and structures derived thereof. If we translate this theory into the structural design of anionic N-heterocyclic carbenes we have to realize that in the carbenes $\mathbf{2}$ and $\mathbf{3}$ one heteroatom is connected to a starred position of the alternant hydrocarbon fragment as shown by $\mathbf{2}_{\text {II }}$ and $\mathbf{3}_{\mathrm{II}}$, respectively. This is a legacy of their origin, as they are deprotonated conjugated heterocyclic mesomeric betaines. By contrast, the pyrimidine derivative $4^{36-39}$ was generated from a cross-conjugated mesomeric betaine. Consequently, the negative charge is exclusively delocalized in the 3-oxobut-1-en-1-olate partial structure without mesomeric charge distribution into the diaminocarbene moiety (c.f. $4_{I}$ ). The $\pi$ electronic charge separation sets molecule $\mathbf{4}$ apart from the other $\mathrm{N}$-heterocyclic carbenes presented in Scheme 1; the connectivity between the two partial structures is exclusively via unstarred positions (c.f. 4II). The relationship between the distinct classes of mesomeric betaines and $\mathrm{N}$-heterocyclic carbenes has been reviewed recently. ${ }^{40}$ Neither the negative charge of the anionic Nheterocyclic carbene $5\left(\mathrm{R}=\mathrm{tBu}_{2} \mathrm{P}\right)^{41}$ nor of dicarbene 6 are delocalized in terms of resonance. Consequently, a lithium cation was found to bind to the nitrogen atom of $\mathbf{5}$ and dicarbene $\mathbf{6}$ has been described as adducts and complexes (e.g. $\mathrm{BF}_{3}$ at $\mathrm{C} 2$ and $\mathrm{Ag} / \mathrm{Ru}$ at $\mathrm{C}^{42}$ or $\mathrm{Li}, \mathrm{V}, \mathrm{Pd}$ at $\mathrm{C} 2$ and $\mathrm{BF}_{3}$ at $\left.\mathrm{C}^{43,44}\right)$. In continuation of our interest in sydnone derived carbenes ${ }^{45}$ we report here on $\mathrm{N}$-heterocyclic carbenes of two sydnone imines, among those the carbene of Molsidomine. This orally active vasodilating drug for the prevention of angina pectoris attacks ${ }^{47}$ is the subject of intense ongoing pharmacological research, ${ }^{48-52}$ however, during the last decade not much effort has been directed toward its chemical properties. We present some surprising results in the light of the relationship between mesomeric betaines and $\mathrm{N}$ heterocyclic carbenes.

\section{Results and Discussion}

Molsidomine 7a is a sydnone imine $\mathrm{e}^{53-57}$ belonging to the class of mesoionic compound ${ }^{58,59}$ and conjugated heterocyclic mesomeric betaines $(\mathrm{CMB})$ of class $1 \mathrm{~B}^{33}$ (Scheme 2 ). It can exclusively be described by a number of dipolar or tetrapolar resonance forms such as $7 \mathbf{a}(\mathbf{A}), 7 \mathbf{a}(\mathbf{B})$ and $7 \mathbf{a}(\mathbf{C})$ from which $7 \mathbf{a}(\mathbf{A})$ is in better agreement with bond lengths (c.f. Supporting Information) and the imine stretching frequencies of the exocyclic imine bond. In continuation of our interest in the chemistry of N-heterocyclic carbenes, ${ }^{60}$ mesomeric betaines ${ }^{61,62}$ and the intersection between these two substance classes we aimed at studying the deprotonation of Molsidomine and of another model sydnone imine at $\mathrm{C} 4$ for comparison, which resulted in the formation of unique anionic N-heterocyclic carbenes. The anion of Molsidomine 7a can be formulated as anionic abnormal NHC $8 \mathbf{a}(\mathbf{A})$ and as anionic normal NHCs $\mathbf{8 a}(\mathbf{B})$. According to the rules of resonance it can even be described by structure $\mathbf{8 a}(\mathbf{C})$ which displays two negative charges on the carbene carbon atom, one of which is delocalized within the $\pi$-electron system, and the other is located in the in-plane $\mathrm{sp}^{2}$ hybrid orbital. The distinct resonance forms of $\mathbf{8 a}$ are reflected in representation 8a. The anionic Nheterocylic carbene 8a differs from the examples presented in Scheme 1 in such a way, that the carbene carbon atom is a starred position of the alternant hydrocarbon fragment itself as shown by a connectivity analysis according to Ramsden's classification ${ }^{33}$
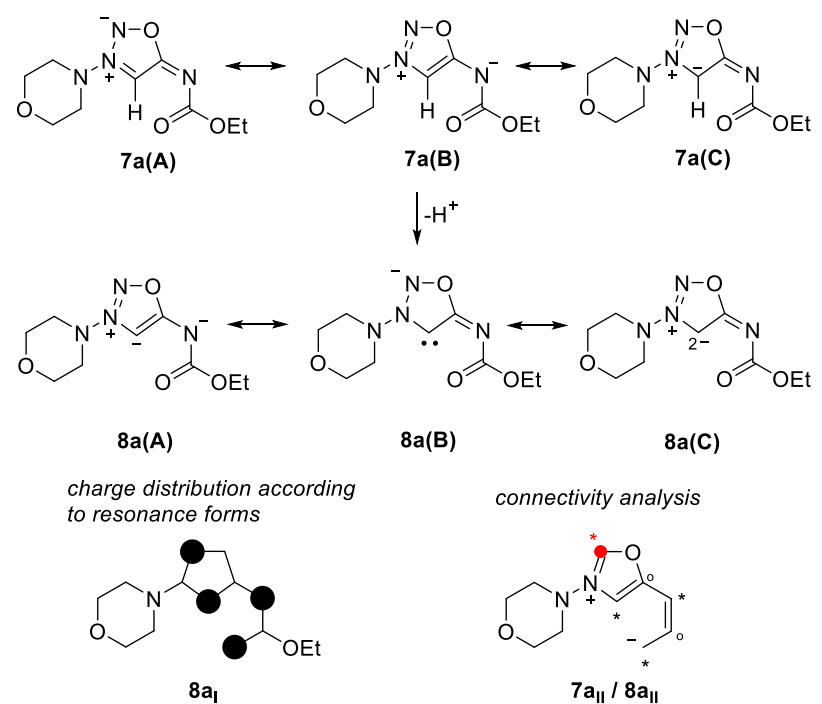

$\downarrow-\mathrm{H}^{+}$ sites of negative charges
Scheme 2. Resonance forms of Molsidomine 7a and of its anion 8a. $\pi$-Electronic charge distribution according to the resonance rules. Connectivity analysis.

According to a DFT calculation at the B3LYP/6-31G(d,p) level the highest occupied molecular orbital (HOMO) of the Molsidomine anion 8a is a $\pi$-orbital which includes a large coefficient of the porbital of $\mathrm{C}-4$, whereas the HOMO-1 corresponds to the characteristic $\sigma$-orbital of NHCs. Thus HOMO and HOMO-1 are switched in comparison to the parent 1,3-dimethylimidazol-2ylidene Im (Figure 1). ${ }^{63}$ In addition, the $\mathrm{E}_{\sigma}$ level changes considerably in comparison to the parent carbene $\left(\Delta \mathrm{E}_{\sigma}(\mathrm{HOMO}\right.$ for Im - HOMO-1 for 8a) $=+3.75 \mathrm{eV}$ ). The lowest unoccupied molecular orbital (LUMO) of carbene 8a is essentially located in the 1,2,3-oxadiazole ring as well as in the conjugated side chain. Its energy is by $1.65 \mathrm{eV}$ higher than that of the parent carbene $\mathbf{I m}$ and it also possesses a large coefficient on the carbene carbon atom. These calculations hint at considerably changed $\pi$-accepting properties of sydnone imine carbenes.

To enable comparisons, a sydnone imine was prepared by a modified HCN-free synthesis according to modified literature procedures $^{64,65}$ starting from 2-methoxyaniline 9 (Scheme 3). Nucleophilic substitution with bromoacetonitrile followed by $\mathrm{N}$ nitrosation gave nitroso compound $\mathbf{1 0}$ which cyclized by gaseous $\mathrm{HCl}$ to form a sydnone imine hydrochloride in quantitative yields. Deprotonation followed by benzoylation gave the sydnone imine $\mathbf{7 b}$ as brownish stable solid. A single crystal analysis of $\mathbf{7 b}$, obtained by slow evaporation from small amounts of DCM, confirmed structure and exocyclic imine bond (Fig. 2).

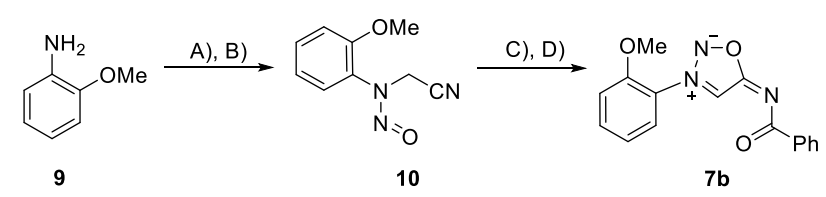

Reaction conditions: A) $\mathrm{BrCH}_{2} \mathrm{CN}, \mathrm{NaOAc}$, EtOH, reflux (83\%); B) $\mathrm{NaNO}_{2}, \mathrm{HCl}$, $\left.\left.0{ }^{\circ} \mathrm{C}(92 \%) ; \mathrm{C}\right) \mathrm{HCl}(\mathrm{g}), \mathrm{Et}_{2} \mathrm{O}, 20{ }^{\circ} \mathrm{C}(99 \%) ; \mathrm{D}\right) \mathrm{PhCOCl}, \mathrm{CH}_{2} \mathrm{Cl}_{2},-10{ }^{\circ} \mathrm{C}$, then $\mathrm{NEt}_{3}(80 \%)$

Scheme 3. Syntheses of sydnone imine $7 \mathbf{b}$. (c.f. 8a 


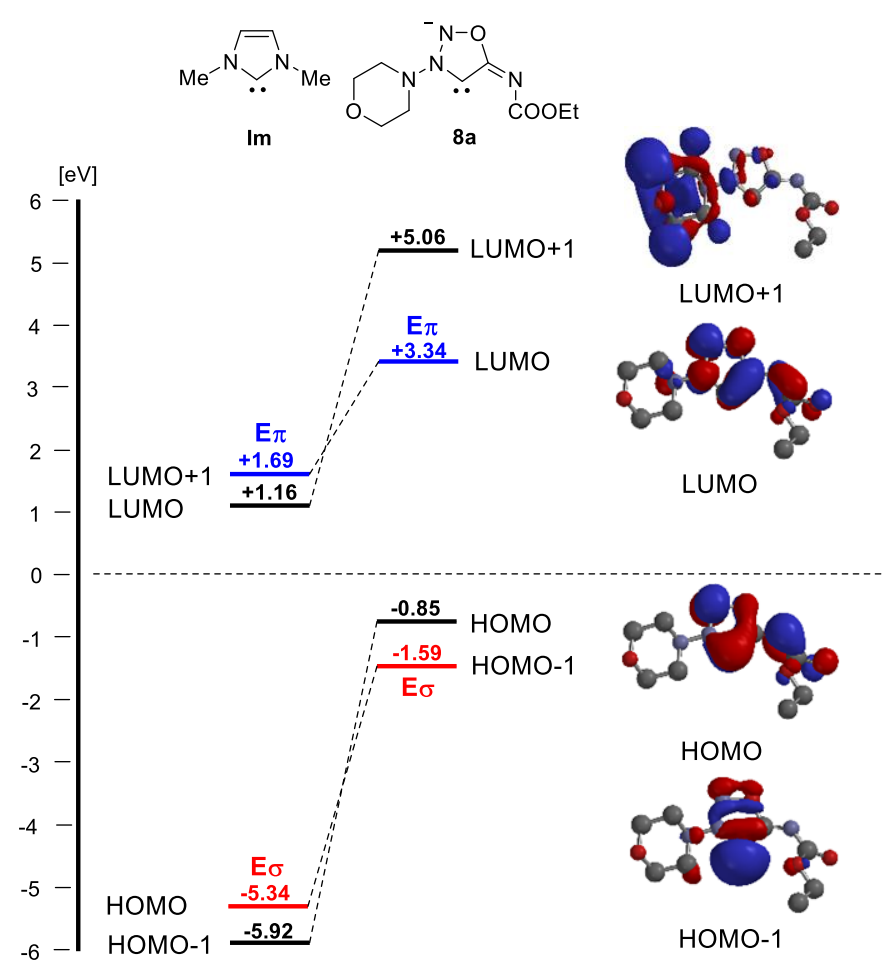

Fig. 1. Frontier orbital energies of 1,3-dimethylimidazol-2-ylidene Im in comparison to Molsidomine carbene $\mathbf{8 a}$.

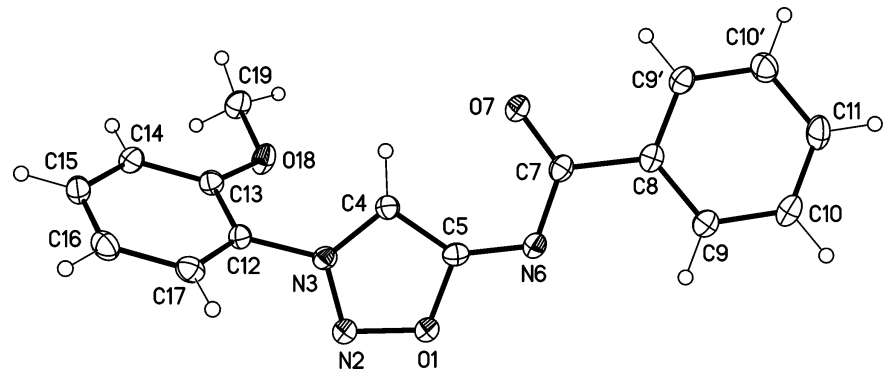

Fig. 2. Molecular drawing of sydnone imine $\mathbf{7 b}$ (displacement parameters are drawn at $50 \%$ probability level). Selected bond lengths [pm] (crystallographic numbering): N3-C4: 134.40(13), C4-C5: 138.65(14), C5-N6: 132.09(13), N6-C7: 137.18(13), C7O7: $123.58(13) \mathrm{pm}$.

To generate and examine anionic $\mathrm{N}$-heterocyclic carbenes of $\mathbf{7 a , b}$ we performed a base screening to circumvent difficulties caused by the known photochemical and thermal sensitivity of sydnone imines ${ }^{66,67}$ as well as their tendency to undergo ring cleavages ${ }^{55}$ or ring transformations. ${ }^{68,69}$ The base $\mathrm{nBuLi}$ initiated several electrophilic attacks despite of a restricted nucleophilicity of $\mathrm{C} 4$ in accordance with some literature data, ${ }^{70}$ however, rapid decomposition at elevated temperatures occurred. ${ }^{71,72}$ We finally found that quantitative deprotonation of Molsidomine 7a and sydnone imine $\mathbf{7 b}$ to give the carbenes $\mathbf{8 a}, \mathbf{b}$ can be achieved on addition of $1 \mathrm{M}$ lithium bis(trimethylsilyl)amide in THF at $\mathrm{rt}$ (Scheme 4).

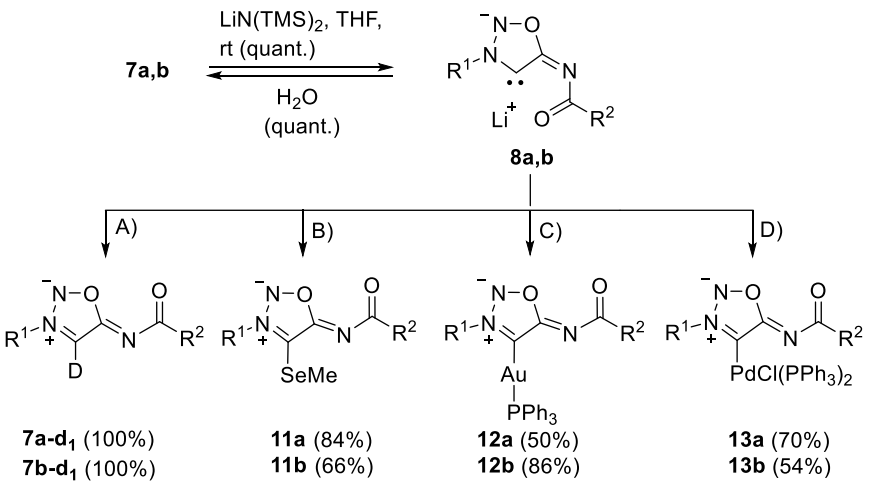

A) MeCN-d ${ }_{3}$, rt B) 1. Se, THF, $\left.0{ }^{\circ} \mathrm{C}, 1 \mathrm{~h} ; 2 . \mathrm{Mel}, \mathrm{rt}, 2 \mathrm{~h} ; \mathrm{C}\right)$ 1. $\left(\mathrm{PPh}_{3}\right) \mathrm{AuCl}, \mathrm{THF},-50{ }^{\circ} \mathrm{C}$, $1 \mathrm{~h} ; 2$. Stirring, rt, $2 \mathrm{~h} ; \mathrm{D}) 1$. $\mathrm{PdCl}_{2}\left(\mathrm{PPh}_{3}\right)_{2}, \mathrm{THF},-50^{\circ} \mathrm{C}, 1 \mathrm{~h} ; 2$. stirring, rt, $2 \mathrm{~h}$.

Scheme 4. Carbene generation and trapping reactions.

Surprisingly the anionic carbenes $\mathbf{8 a}, \mathbf{b}$ proved to be stable at $\mathrm{rt}$ in solution under an inert atmosphere over a period of several weeks. According to the DFT calculation the lithium cation is located between the oxygen of the carbonyl group and the carbene carbon atom, and the bond distances were calculated to be 199.8 (C4-Li) and $176.8 \mathrm{pm}(\mathrm{C}=\mathrm{O}-\mathrm{Li})$. Traces of water protonated the carbenes $\mathbf{8 a}, \mathbf{b}$ spontaneously to give the starting materials without any traces of decomposition products. Performing the reaction in MeCN- $\mathbf{d}_{3}$ gave the C4-deuterated sydnone imines $\mathbf{7} \mathbf{a}-\mathbf{d}_{\mathbf{1}}$ and $\mathbf{7 b - \mathbf { d } _ { \mathbf { 1 } }}$ in quantitative yields, respectively, which are not formed starting from 7a,b without base even after $24 \mathrm{~h}$ upon warming to $50{ }^{\circ} \mathrm{C}$ under identical conditions (Scheme 4). Replacement of the lithium of the resulting anionic NHC 8a,b to potassium by addition of $\mathrm{KOtBu}$ induced a spontaneous decomposition, and the same is true for deprotonations of $\mathbf{7 a , b}$ by addition of $1 \mathrm{M}$ potassium bis(trimethylsilyl)amide in THF. The carbene carbon atoms of $\mathbf{8 a}, \mathbf{b}$ are extremely shielded, and resonance frequencies at $\delta=$ $142.1 \mathrm{ppm}$ and $159.8 \mathrm{ppm}$ for $\mathbf{8 a}$ and $\mathbf{8 b}$ were measured, respectively. These resonance frequencies set the carbenes 8a,b apart from other $\pi$-conjugated and $\pi$-cross-conjugated NHCs and anionic NHCs mentioned before. The sydnone imine carbenes 8a,b were then trapped by selenium followed by methylation to give the first selenium derivatives of sydnone imines 11a,b in good yields. The chemical shifts of the $\mathrm{C} 4$ carbon atom were detected between $\delta=98.4$ ppm (11a) and $107.1 \mathrm{ppm}(\mathbf{1 1 b})$ in the ${ }^{13} \mathrm{C}$ NMR spectra, while ${ }^{77} \mathrm{Se}$ chemical shifts were found between $\delta=97.2$ ppm (11a) and $106.9 \mathrm{ppm}$ (11b). Unambiguous structure elucidation was accomplished by ${ }^{1} \mathrm{H},{ }^{77} \mathrm{Se}-\mathrm{HMBC}$ measurements to exclude isomers. The sydnone imine carbenes $\mathbf{8 a , b}$ were also trapped as gold complexes $\mathbf{1 2 a}$,b by $\left(\mathrm{PPh}_{3}\right) \mathrm{AuCl}$. The chemical shifts of the $\mathrm{C} 4$ carbon atom were detected between $\delta=145.2 \mathrm{ppm}$ (12a) and $156.0 \mathrm{ppm}(\mathbf{1 2 b})$ in the ${ }^{13} \mathrm{C}$ NMR spectra. The $\mathrm{C} 4{ }^{13} \mathrm{C}$ NMR chemical shifts of the gold complexes are closely comparable to its preceding carbenes $\mathbf{8 a}, \mathbf{b}$, however, large coupling constants for the $\mathrm{C} 4$ atom were observed. Thus, ${ }^{2} J_{\mathrm{C} 4, \mathrm{P}}$ of 12a was measured to be $125.5 \mathrm{~Hz}$. Single crystals of $\mathbf{1 2 b}$ have been subjected to an X-ray crystal structure analysis (Fig. 3). To the best of our knowledge, gold complexes of 1,2,3-oxadiazoles have been unknown to date. 


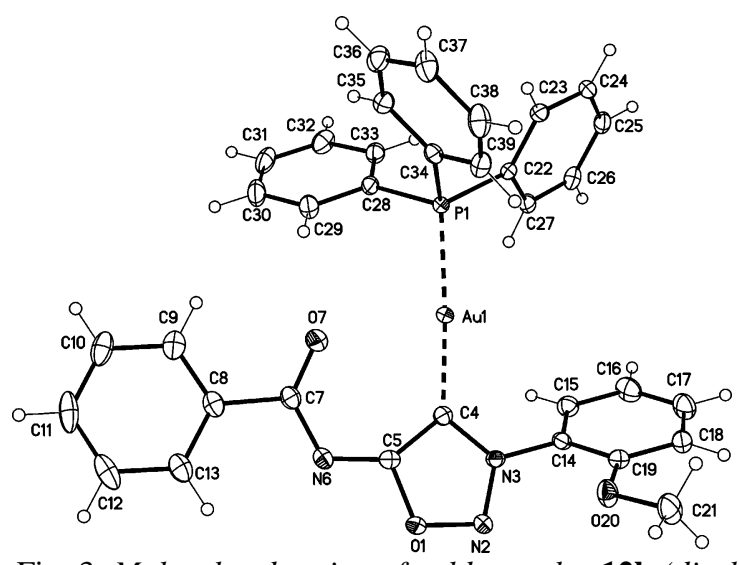

Fig. 3. Molecular drawing of gold complex $\mathbf{1 2 b}$ (displacement parameters are drawn at $50 \%$ probability level). Selected bond lengths [pm] (crystallographic numberings): O1-N2: 136.4(2), N2-N3: 132.O(2), N3-C4: 136.7(3), C4-C5: 140.3(3), C5-O1: 139.3(2), C5-N6: 132.6(3), N6-C7: 135.8(3), C7-O7: 123.4(3), Aul-C4: 203.3(2) pm.

The sydnone imine carbenes 8a,b were also trapped with $\mathrm{Pd}(\mathrm{II}) \mathrm{Cl}_{2}\left(\mathrm{PPh}_{3}\right)_{2}$ to give the trans-palladium complexes 13a,b in moderate yields (Scheme 4 ). The chemical shifts of the $\mathrm{C} 4$ carbon atom were detected at $\delta=118.0 \mathrm{ppm}(\mathbf{1 3 a})$ and $128.6 \mathrm{ppm}(\mathbf{1 3 b})$ in the ${ }^{13} \mathrm{C}$ NMR spectra. To the best of our knowledge, these are first examples of sydnone imine carbene Pd complexes. Single crystals of 13b have been subjected to an X-ray analysis and the molecular drawing is shown in Fig. 4. In comparison to the mesomeric betaine 7b a shortening of the N6-C7 bond (crystallographic numbering) by $4.9 \mathrm{pm}$ and a prolongation of the carbonyl bond $\mathrm{C} 7-\mathrm{O} 7$ bond by $1.7 \mathrm{pm}$ are observed.

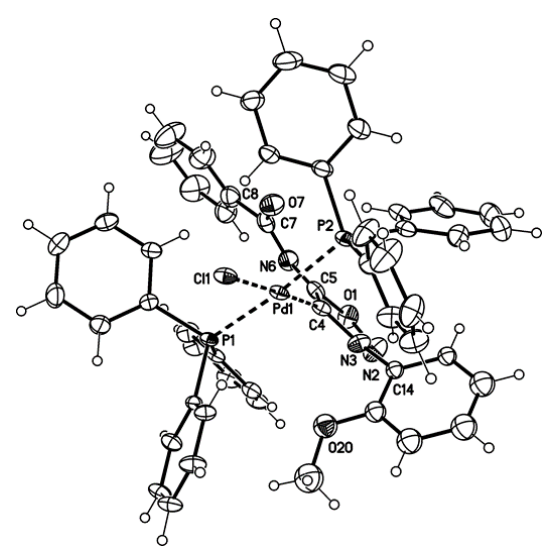

Fig. 4. Molecular drawing of palladium complex $\mathbf{1 3 b}$ (solvent and minor disordered part of the o-methoxyphenyl substituent omitted for clarity, displacement parameters are drawn at $50 \%$ probability level). Selected bond lengths [pm] (crystallographic numberings): O1-N2: 135.8(5), N2-N3: 132.4(5), N3-C4: 136.1(5), C4-C5: 140.3(5), C5-O1: 137.3(5), C5-N6: 131.7(5), N6-C7: 132.3(6), C7-O7: 125.3(5), Pd1-C4: 201.5(4) pm.

We then tested the Pd complexes 13a,b as catalysts in SuzukiMiyaura and Sonogashira-Hagihara cross-couplings. For the former reaction, we chose 2,5-dibromo-3,4-dinitrothiophene as starting material and performed coupling reactions with phenylboronic acid, 1-naphthylboronic acid and 2- thiophenylboronic acid (Scheme 5). Compound 14a has been prepared before in $37 \%$ yield on employing tetrakis(triphenylphosphine) palladium $(0)$ as the catalyst. ${ }^{73}$ The compound 14b has been prepared before in $80 \%$ by using $\mathrm{N}$ phenylsydnone-palladium complexes as catalysts. ${ }^{45,46}$ The yields of compound $\mathbf{1 4 c}$ are comparable to those which are described in the literature which were achieved with bis(triphenylphosphine)palladium(II)dichloride in THF as the solvent. ${ }^{74}$

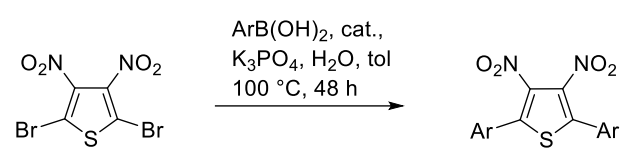

14a: $\mathrm{Ar}=\mathrm{Ph}$ (cat. 13a: $77 \%$; cat. 13b: $62 \%$ ) 14b: $\mathrm{Ar}=1$-naphth (cat. 13a: $68 \%$; cat. 13b: $50 \%$ ) 14c: $\mathrm{Ar}=2$-thiophen (cat 13a: $67 \%$; cat 13b: $52 \%$ )

Scheme 5. Sydnone imine Pd complexes as catalysts in SuzukiMiyaura reactions.

The Sonogahira-Hagihara reactions were performed starting from 2-methyl-3-butyn-2-ol which was coupled with bromobenzene, 1bromonaphthalene and 3-bromothiophene, respectively (Scheme 6). The yields of 15a are comparable to those described in the literature which were achieved with bis(triphenylphosphine)palladium(II)dichloride in the presence of ammonium chloride. ${ }^{75}$ The yields of the acetylenes $\mathbf{1 5} \mathbf{b}$ were much better than in the literature, ${ }^{76}$ although longer reaction times were required. Compound 15c has been prepared before in $45 \%$ yield on employing bis(acetonitrile)dichloropalladium(II) as the catalyst. ${ }^{77}$

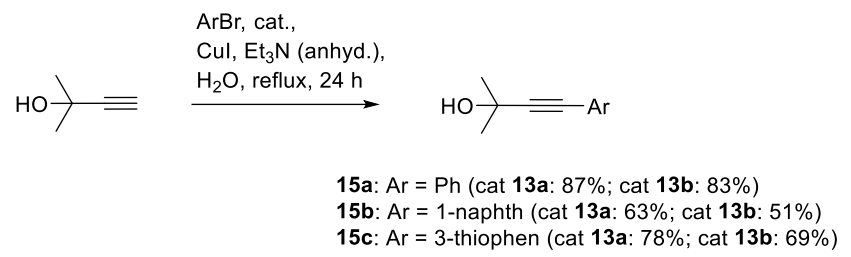

Scheme 6. Sydnone imine Pd complexes as catalysts in Sonogashira-Hagihara reactions.

\section{Conclusion}

In conclusion, Molsidomine as well as the model sydnone imine form anionic $\mathrm{N}$-heterocyclic carbenes on deprotonation, the ${ }^{13} \mathrm{C}$ NMR resonance frequencies of which appear at unusually high field, i.e. at $\delta=142.1 \mathrm{ppm}$ and $159.8 \mathrm{ppm}$, respectively. The carbenes gave selenium adducts, gold complexes as well as palladium complexes. The latter proved to be active as catalysts in Suzuki-Miyaura and Sonogashira-Hagihara couplings. These results supplement our knowledge on sydnones ${ }^{78}$ and their relationship to the substance class of $\mathrm{N}$-heterocyclic carbenes. ${ }^{40}$

\section{Acknowledgement}

Dr. Gerald Dräger, university of Hannover (Germany), is greatfully acknowledged for measuring the HR-ESI-MS spectra. The Deutsche Forschungsgemeinschaft (DFG) is gratefully acknowledged for financial support. 


\section{Experimental Section}

General considerations. Flash-chromatography was performed with silica gel 60 (0.040-0.063 mm). Nuclear magnetic resonance (NMR) spectra were obtained with a Bruker Avance 400 and Bruker Avance III $600 \mathrm{MHz} .{ }^{1} \mathrm{H}$ NMR spectra were recorded at $400 \mathrm{MHz}$ or $600 \mathrm{MHz}$ and ${ }^{13} \mathrm{C}$ NMR spectra were measured at $100 \mathrm{MHz}$ or $150 \mathrm{MHz}$, with the solvent peak or tetramethylsilane used as the internal reference. Multiplicities are described by using the following abbreviations: $\mathrm{s}=$ singlet, $\mathrm{d}=$ doublet, $\mathrm{t}=$ triplet, $\mathrm{q}=$ quartet, and $\mathrm{m}$ $=$ multiplet. Signal orientations in DEPT experiments were described as follows: o = no signal; $+=\operatorname{up}\left(\mathrm{CH}, \mathrm{CH}_{3}\right) ;-=$ down $\left(\mathrm{CH}_{2}\right)$. The numbering of the compounds is not always in accordance with IUPAC rules to allow comparisons ("spectroscopic numbering"). FT-IR spectra were obtained on a Bruker Vector 22 in the range of 400 to $4000 \mathrm{~cm}^{-1}$. Melting points were measured by differential scanning calorimetry (DSC) using a DSC 6 apparatus (Perkin Elmer). The electrospray ionization mass spectra (ESIMS) were taken with an Agilent LCMSD series HP 1100 with APIES at a fragmentor voltage of $30 \mathrm{~V}$ unless otherwise noted. Samples were dissolved in $\mathrm{MeOH}$ and sprayed from $\mathrm{MeCN}$ at $4000 \mathrm{~V}$ capillary voltage. The HR-MS spectra were measured on a Bruker Daltonik Tesla-Fourier transform - ion cyclotron resonance mass spectrometer with electrospray ionisation. Yields are not optimized.

Crystal Structure Determinations. The single-crystal X-ray diffraction study was carried out on a Bruker D8 Venture diffractometer with Photon100 detector at $123(2) \mathrm{K}$ using $\mathrm{Cu}-\mathrm{K} \alpha$ radiation $(\lambda=1.54178 \AA$ ) $(7 \mathbf{b})$ or Mo-K $\alpha$ radiation $(\lambda=0.71073 \AA)(\mathbf{1 2 b}, \mathbf{1 3 b})$. Direct Methods $(\mathbf{7 b})$ or Patterson Methods (12b, 13b) (SHELXS-97) ${ }^{79}$ were used for structure solution and refinement was carried out using SHELXL-2014 (full-matrix least-squares on $\left.\mathrm{F}^{2}\right){ }^{80}$ Hydrogen atoms were localized by difference electron density determination and refined using a riding. Semi-empirical absorption corrections and extinction correction were applied. In $\mathbf{1 3 b}$ the $o$ methoxyphenyl substituent is disordered (see cif-file for details).

7b: yellow crystals, $\mathrm{C}_{16} \mathrm{H}_{13} \mathrm{~N}_{3} \mathrm{O}_{3}, \mathrm{M}=295.29$, crystal size $0.45 \times 0.35 \times 0.30$ $\mathrm{mm}$, orthorhombic, space group Pbca (no. 61), $\mathrm{a}=11.4610$ (3) $\AA$, $\mathrm{b}=11.3954$ (3) $\AA, c=21.6786$ (6) $\AA, V=2831.28$ (13) $\AA^{3}, Z=8, \rho($ calc $)=1.386 \mathrm{Mg} \mathrm{m}^{-3}$, $\mathrm{F}(000)=1232, \mu(\mathrm{MoK} \alpha)=0.81 \mathrm{~mm}^{-1}, 20087$ reflections $\left(\theta_{\max }=72.2^{\circ}\right), 2781$ unique $\left[R_{\text {int }}=0.024\right], 201$ parameters, $R 1$ (for $\left.2668 \mathrm{I}>2 \sigma(\mathrm{I})\right)=0.032$, wR2 (all data) $=0.081, \mathrm{~S}=1.05$, largest diff. peak and hole 0.23 and $-0.20 \mathrm{e} \AA^{-3}$. 12b: colorless crystals, $\mathrm{C}_{34} \mathrm{H}_{27} \mathrm{AuN}_{3} \mathrm{O}_{3} \mathrm{P}, \mathrm{M}=753.52$, crystal size $0.28 \times 0.22$ $\times 0.18 \mathrm{~mm}$, monoclinic, space group P21/n (no. 14), a = 13.2351 (6) $\AA$, b = 14.9811 (7) $\AA, c=15.3479$ (8) $\AA$, $\beta=106.184(2)^{\circ}, V=2922.5$ (2) $\AA^{3}, Z=4$, $\rho($ calc $)=1.713 \mathrm{Mg} \mathrm{m}^{-3}, \mathrm{~F}(000)=1480, \mu(\mathrm{MoK} \alpha)=5.13 \mathrm{~mm}^{-1}, 65092$ reflections $\left(\theta_{\max }=27.5^{\circ}\right), 6714$ unique [ $\mathrm{R}_{\text {int }}=0.029$ ], 381 parameters, $\mathrm{R} 1$ (for $6191 \mathrm{I}>2 \sigma(\mathrm{I}))=0.017, \mathrm{wR} 2$ (all data) $=0.039, \mathrm{~S}=1.19$, largest diff. peak and hole 1.21 and -0.64 e $\AA^{-3}$

13b: yellow crystals, $\mathrm{C}_{52} \mathrm{H}_{42} \mathrm{ClN}_{3} \mathrm{O}_{3} \mathrm{P}_{2} \mathrm{Pd} \cdot \mathrm{CH}_{2} \mathrm{Cl}_{2}, \mathrm{M}=1045.60$, crystal size $0.20 \times 0.14 \times 0.08 \mathrm{~mm}$, monoclinic, space group $\mathrm{P} 21 / \mathrm{c}$ (no. 14 ), $\mathrm{a}=17.0717$ (7) $\AA, \mathrm{b}=13.6507$ (6) $\AA, \mathrm{c}=21.5274$ (8) $\mathrm{\AA}, \beta=108.203(1)^{\circ}, \mathrm{V}=4765.7$ (3) $\AA^{3}, \mathrm{Z}=4, \rho($ calc $)=1.457 \mathrm{Mg} \mathrm{m}^{-3}, \mathrm{~F}(000)=2136, \mu(\mathrm{CuK \alpha})=0.67 \mathrm{~mm}^{-1}$, 135804 reflections $\left(\theta_{\max }=27.6^{\circ}\right), 10975$ unique $\left[\mathrm{R}_{\text {int }}=0.066\right], 550$ parameters, 22 restraint, $\mathrm{R} 1$ (for $8653 \mathrm{I}>2 \sigma(\mathrm{I}))=0.055, \mathrm{wR} 2$ (all data) $=0.137, \mathrm{~S}=1.06$,

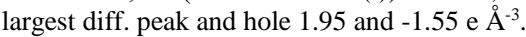

CCDC 1541425 (7b), CCDC 1541426 (12b), and CCDC 1541427 (14b) contain the supplementary crystallographic data for this paper. These data can be obtained free of charge from The Cambridge Crystallographic Data Centre via www.ccdc.cam.ac.uk/data_request/cif.

Calculations. All density-functional theory (DFT)-calculations were carried out by using the current Spartan Software (Spartan'16, Wavefunction, Inc., Irvine, CA. Available from: http://www.wavefun.com) running on an Intel ${ }^{\circledR}$ CoreTM i7-6950X deca-core system equipped with 64 GB RAM main memory and sufficient solid-state disc space. MMFF optimized structures were used as starting geometries. Then, the B3LYP density functional and the 6-31G(d,p) basis set was used in order to allow for comparison with previous results. ${ }^{63} \mathrm{All}$ final structures were proven to be true minima by the absence of imaginary frequencies or transition states by the occurrence of a negative frequency.

\section{Synthesis of sydnone imine $7 \mathbf{b}$.}

N-(o-Methoxyphenyl)-aminoacetonitrile. 2-Methoxyaniline (5.00 g, 40.6 $\mathrm{mmol})$, bromoacetonitrile $(5.84 \mathrm{~g}, 48.7 \mathrm{mmol})$, sodium acetate trihydrate $(6.63$ g, $48.7 \mathrm{mmol}$ ) and $30 \mathrm{~mL}$ of EtOH were mixed in a $100 \mathrm{~mL}$ flask equipped with a reflux condenser. The mixture was heated to $80^{\circ} \mathrm{C}$ and stirred for $24 \mathrm{~h}$. Afterwards the cooled mixture was poured into $250 \mathrm{~mL}$ of iced water. The aqueous phase was extracted three times with DCM. Then the combined organic phases were dried over $\mathrm{MgSO}_{4}$ and the solvent was evaporated in vacuo. The product was purified by recrystallization from EtOH. Yield: 5.46
$(83 \%)$ of a brown solid. ${ }^{1} \mathrm{H}$ NMR $\left(400 \mathrm{MHz} \mathrm{CDCl}_{3}\right): \delta=6.93-6.97(\mathrm{~m}, 1 \mathrm{H}$, 3-H), 6.83-6.85 (m, 2H, 4/5-H), 6.70-6.72 (m, 1H, 2-H), 4.57 (br. s, 1H, 9-H), $4.15\left(\mathrm{~d}, 2 \mathrm{H},{ }^{3} J_{\mathrm{H}, \mathrm{H}}=7.0 \mathrm{~Hz}, 10-\mathrm{H}\right), 3.86(\mathrm{~s}, 3 \mathrm{H}, 8-\mathrm{H}) \mathrm{ppm}$. Spectroscopic data are in agreement with those reported in the literature. ${ }^{8}$

N-(o-Methoxyphenyl)-N-nitrosoaminoacetonitrile (10). Into a $250 \mathrm{~mL}$ flask $\mathrm{N}$-(o-methoxyphenyl)-aminoacetonitrile $(10.60 \mathrm{~g}, 65.4 \mathrm{mmol})$ and $50 \mathrm{~mL}$ of hydrochloric acid $(12.5 \%)$ were given and cooled to $0{ }^{\circ} \mathrm{C}$. To this suspension a solution of sodium nitrite $(6.76 \mathrm{~g}, 98.0 \mathrm{mmol})$ in $10 \mathrm{~mL}$ water was added slowly. After $30 \mathrm{~min}$ of stirring at $0^{\circ} \mathrm{C} 50 \mathrm{~mL}$ of $\mathrm{Et}_{2} \mathrm{O}$ were added and the mixture was stirred for an additional $1.5 \mathrm{~h}$ at that temperature. After warming to rt, additional $50 \mathrm{~mL}$ of $\mathrm{Et}_{2} \mathrm{O}$ were added. The two phases were separated and the aqueous layer was extracted three times with DCM. The combined organic phases were dried over $\mathrm{MgSO}_{4}$, the solvent was evaporated in vacuo and the resulting solid was purified by recrystallization from EtOH. Yield: $11.51 \mathrm{~g}(92$ $\%$ ) of a brown solid. ${ }^{1} \mathrm{H}$ NMR $\left(400 \mathrm{MHz}, \mathrm{CDCl}_{3}\right): \delta=7.45-7.53(\mathrm{~m}, 2 \mathrm{H}, 3 / 5-$ $\mathrm{H}), 7.08-7.14$ (m, 2H, 2/4-H), 4.66 (s, 2H, 10-H), 3.93 (s, 3H, 8-H) ppm. The compound is known from the literature (without comparable NMR-spectra). ${ }^{64}$

N-(o-Methoxyphenyl)-sydnonimine hydrochloride. Into a suspension of $\mathrm{N}$ (o-methoxyphenyl)-N-nitrosoaminoacetonitrile (4.73 g, $24.7 \mathrm{mmol})$ in $30 \mathrm{~mL}$ $\mathrm{Et}_{2} \mathrm{O}$ (abs.) in a two-necked flask, gaseous hydrochloric acid was passed for 3 h. The reaction temperature was held at $20^{\circ} \mathrm{C}$. At the bottom layer of the flask the formation of black oil was observed. After separation of the layers, the black oil was washed three times with $\mathrm{Et}_{2} \mathrm{O}$ and dried in vacuo. A solid could only be obtained after several hours of drying in vacuo. Adding any solvent other then $\mathrm{Et}_{2} \mathrm{O}$ immediately resulted in the formation of an oily compound again. Therefore further purification was not possible. Yield: 5.580 (99\%, crude product) of a dark brown solid. ${ }^{1} \mathrm{H}$ NMR (400 MHz, DMSO-d 6 ): $\delta=$ 10.15 (s, 2H, 6-H), 8.38 (s, 1H, 4-H), 7.73-7.80 (m, 2H, 10/12-H), 7.45-7.49 $(\mathrm{m}, 1 \mathrm{H}, 9-\mathrm{H}), 7.21-7.25(\mathrm{~m}, 1 \mathrm{H}, 11-\mathrm{H}), 3.91(\mathrm{~s}, 3 \mathrm{H}, 14-\mathrm{H}) \mathrm{ppm}$. The compound is known from the literature (without comparable NMR-spectra). ${ }^{64}$

N3-(o-Methoxyphenyl)-N6-benzoylsydnone imine (7b). Benzoyl chloride (1.10 $\mathrm{mL}, 9.49 \mathrm{mmol})$ was added to a solution of N-(o-methoxyphenyl)sydnonimine hydrochloride $(1.80 \mathrm{~g}, 7.91 \mathrm{mmol})$ in $15 \mathrm{~mL}$ of DCM (abs.) in a $50 \mathrm{~mL}$ flask. The solution was cooled to $-10{ }^{\circ} \mathrm{C}$ and triethylamine $(2.65 \mathrm{~mL}$, $18.98 \mathrm{mmol}$ ) in $5 \mathrm{~mL} \mathrm{DCM}$ (abs.) was added dropwise. The mixture was stirred for $1 \mathrm{~h}$ at the same temperature, then warmed to rt and stirred for another $16 \mathrm{~h}$. Afterwards $100 \mathrm{~mL}$ of water were added. The aqueous layer was extracted three times with DCM. The combined organic layers were dried over $\mathrm{MgSO}_{4}$ and the solvent was evaporated in vacuo. Purification was achieved by column chromatography (silica gel, DCM : $\mathrm{MeOH}=40: 1)$. Yield: $1.86 \mathrm{~g}(80 \%)$ of a brown solid, mp: $199{ }^{\circ} \mathrm{C}$ (decomposition). ${ }^{1} \mathrm{H}$ NMR $\left(400 \mathrm{MHz}, \mathrm{CDCl}_{3}\right): \delta=$ 8.54 (s, 1H, 4-H), 8.30-8.32 (m, 2H, 9/9'-H), 7.63-7.69 (m, 2H, 15/17-H), 7.47$7.51(\mathrm{~m}, 1 \mathrm{H}, 11-\mathrm{H}), 7.42-7.45(\mathrm{~m}, 2 \mathrm{H}, 10 / 10$ '- $\mathrm{H}), 7.16-7.21(\mathrm{~m}, 2 \mathrm{H}, 14 / 16-\mathrm{H})$, 3.97 (s, 3H, 19-H) ppm; $\left.{ }^{13} \mathrm{C} \mathrm{NMR} \mathrm{(100} \mathrm{MHz,} \mathrm{CDCl}_{3}\right): \delta=174.3$ (o, C5), 174.1 (o, C7), 152.3 (o, C13), 137.2 (o, C8), 134.1 (+, C15), 131.4 (+, C11), 129.4 (+, C9/C9'), 128.0 (+, C10/C10'), $125.6(+, \mathrm{C} 17), 122.7$ (o, C12), $121.3(+$, C16), 113.0 (+, C14), 108.9 (+, C4), 56.4 (+, C19) ppm; ${ }^{15} \mathrm{~N}$ NMR (60 MHz, $\mathrm{CDCl} 3): \delta=-29.6(\mathrm{~N} 6),-104.7$ (N3), -202.7 (N2) ppm; IR (ATR): 3151, 3054, 2838, 1613, 1577, 1548, 1501, 1354, 1318, 1286, 1262, 1211, 1165, 1022, 957 , $929,858,750,707,674 \mathrm{~cm}^{-1}$; MS (ESI $\left.30 \mathrm{~V}\right) \mathrm{m} / \mathrm{z}(\%)=296.0(80)\left[\mathrm{M}+\mathrm{H}^{+}\right]$, 318.1 (100) $\left[\mathrm{M}+\mathrm{Na}^{+}\right], 613.2$ (79) $\left[2 \mathrm{M}+\mathrm{Na}^{+}\right]$. HR-ESI-MS: calcd for $\mathrm{C}_{16} \mathrm{H}_{14} \mathrm{~N}_{3} \mathrm{O}_{3}{ }^{+}$296.1035. Found 296.1032 (100\%).

4-Lithiomolsidomine (8a). In an NMR tube a dry sample of Molsidomine $(0.022 \mathrm{~g}, 0.091 \mathrm{mmol})$ was dissolved in $0.4 \mathrm{~mL}$ of anhydrous THF-d $\mathrm{d}_{8}$ under an inert atmosphere. Then a 1M solution of LHMDS in THF $(0.109 \mathrm{~mL}, 0.109$ mmol) was added to give the lithium adduct in quantitative yields. ${ }^{1} \mathrm{H}$ NMR $\left(600 \mathrm{MHz}, \mathrm{THF}-\mathrm{d}_{8}\right): \delta=4.07\left(\mathrm{q}, J_{\mathrm{H}, \mathrm{H}}=7.1 \mathrm{~Hz}, 2 \mathrm{H}, 9-\mathrm{H}\right), 3.78\left(\mathrm{t}, J_{\mathrm{H}, \mathrm{H}}=4.6 \mathrm{~Hz}\right.$, $\left.4 \mathrm{H}, 13 / 13^{\circ}-\mathrm{H}\right), 3.37\left(\mathrm{t}, J_{\mathrm{H}, \mathrm{H}}=4.6 \mathrm{~Hz}, 4 \mathrm{H}, 12 / 12^{\prime}-\mathrm{H}\right), 1.17\left(\mathrm{t}, J_{\mathrm{H}, \mathrm{H}}=7.1 \mathrm{~Hz}, 3 \mathrm{H}\right.$, 10-H) ppm; ${ }^{13} \mathrm{C}$ NMR (150 MHz, THF-d 8 ): $\delta=185.4$ (o, C5), 162.9 (o, C7), 142.1 (o, C4), 66.7 (- , C13/C13`), 61.5 (-, C9), 56.2 (-, C12/C12‘), $15.3(+$, C10) ppm.

4-Lithio-N3-(o-methoxyphenyl)-N6-benzoylsydnonimine (8b). In an NMR tube a dry sample of N3-(o-methoxyphenyl)-N6-benzoylsydnonimine $(0.022$ $\mathrm{g}, 0.075 \mathrm{mmol}$ ) was dissolved in $0.4 \mathrm{~mL}$ of anhydrous $\mathrm{THF}-\mathrm{d}_{8}$ under an inert atmosphere. Then a $1 \mathrm{M}$ solution of LHMDS in THF $(0.089 \mathrm{~mL}, 0.089 \mathrm{mmol})$ was added to give the lithium adduct in quantitative yields. ${ }^{1} \mathrm{H} \mathrm{NMR}(600 \mathrm{MHz}$, THF-d $\left.{ }_{8}\right): \delta=8.25-8.24\left(\mathrm{~m}, 2 \mathrm{H}, 9 / 9^{\prime}-\mathrm{H}\right), 7.48-7.51(\mathrm{~m}, 1 \mathrm{H}, 15-\mathrm{H}), 7.46-7.47$ $(\mathrm{m}, 1 \mathrm{H}, 17-\mathrm{H}), 7.22-7.25(\mathrm{~m}, 1 \mathrm{H}, 11-\mathrm{H}), 7.19-7.20(\mathrm{~m}, 1 \mathrm{H}, 14-\mathrm{H}), 7.13-7.16$ (m, 2H, 10/10'-H), 7.05-7.07 (m, 1H, 16-H), 3.73 (s, 3H, 19-H) ppm. ${ }^{13} \mathrm{C}$ NMR (150 MHz, THF-d 8 ): $\delta=185.4$ (o, C5), 170.4 (o, C7), 159.8 (o, C4), 154.9 (o, C13), 140.8 (o, C8), 131.8 (+, C15), 130.8 (o, C12), 130.1 (+, C11), 129.8 (+, C9/C9'), $128.2(+, \mathrm{C} 17), 127.9\left(+, \mathrm{C} 10 / \mathrm{C} 10^{\circ}\right), 121.0$ (+, C16), $113.4(+, \mathrm{C} 14)$, $56.1(+, \mathrm{C} 19) \mathrm{ppm}$. 
4-(Methylseleno)-molsidomine (11a). Under an inert atmosphere Molsidomine ( $0.24 \mathrm{~g}, 1.00 \mathrm{mmol})$ was dissolved in $15 \mathrm{~mL}$ of THF (abs.). Then a $1 \mathrm{M}$ solution of LHMDS in THF $(1.20 \mathrm{~mL}, 1.20 \mathrm{mmol})$ was added and the mixture was cooled to $0{ }^{\circ} \mathrm{C}$. Selenium $(0.10 \mathrm{~g}, 1.20 \mathrm{mmol})$ was added and the mixture was stirred for $0.5 \mathrm{~h}$. Then iodomethane $(0.08 \mathrm{~mL}, 1.20 \mathrm{mmol})$ was added. The mixture was stirred for an additional $0.5 \mathrm{~h}$ at $0{ }^{\circ} \mathrm{C}$, then slowly warmed to $\mathrm{rt}$ and stirred for another $2 \mathrm{~h}$. Afterwards the solvent was evaporated in vacuo. The crude product was purified by column chromatography (DCM:MeOH 25:1). Yield: $0.282 \mathrm{~g}(84 \%)$ of a brownish solid, mp: $212{ }^{\circ} \mathrm{C}$ (decomposition); ${ }^{1} \mathrm{H}$ NMR (400 MHz, $\mathrm{CDCl}_{3}$ ): $\delta=4.17$ (q, $J_{\mathrm{H}, \mathrm{H}}=7.1 \mathrm{~Hz}, 2 \mathrm{H}$, 9-H), $3.94\left(\mathrm{t}, J_{\mathrm{H}, \mathrm{H}}=4.5 \mathrm{~Hz}, 4 \mathrm{H}, 13 / 13^{\circ}-\mathrm{H}\right), 3.49\left(\mathrm{t}, J_{\mathrm{H}, \mathrm{H}}=4.5 \mathrm{~Hz}, 4 \mathrm{H}, 12 / 12^{\circ}\right.$ $\mathrm{H}), 2.39$ (s, 16-H), 1.29 (t, $\left.J_{\mathrm{H}, \mathrm{H}}=7.1 \mathrm{~Hz}, 3 \mathrm{H}, 10-\mathrm{H}\right) \mathrm{ppm} ;{ }^{13} \mathrm{C} \mathrm{NMR}(100 \mathrm{MHz}$, $\left.\mathrm{CDCl}_{3}\right): \delta=186.6(\mathrm{o}, \mathrm{C} 5), 159.5(\mathrm{o}, \mathrm{C} 7), 98.4(\mathrm{o}, \mathrm{C} 4), 66.0\left(-, \mathrm{C} 13 / \mathrm{C} 13^{\circ}\right), 61.3$ $(-, \mathrm{C} 9), 55.3\left(-, \mathrm{C} 12 / \mathrm{C}_{2}{ }^{\circ}\right), 14.5(+, \mathrm{C} 10), 7.9(+, \mathrm{C} 16) \mathrm{ppm} ;{ }^{77} \mathrm{Se}$ NMR $(114$ $\mathrm{MHz}, \mathrm{CDCl}_{3}$ ): $\delta=97.2$ (s) ppm; IR (ATR): 2972, 2932, 2900, 2858, 1662, $1592,1405,1371,1198,1146,1100,1056,1042,1024,934,882,791 \mathrm{~cm}-1$ MS (ESI $10 \mathrm{~V}) \mathrm{m} / \mathrm{z}(\%)=337.0(100)\left[\mathrm{M}+\mathrm{H}^{+}\right], 359.0(40)\left[\mathrm{M}+\mathrm{Na}^{+}\right], 695.0$ (100) $\left[2 \mathrm{M}+\mathrm{Na}^{+}\right]$. HR-ESI-MS: calcd for $\mathrm{C}_{10} \mathrm{H}_{17} \mathrm{~N}_{4} \mathrm{O}_{4} \mathrm{Se}^{+}$337.0415. Found 337.0414 .

4-(Methylseleno)-N3-(o-methoxyphenyl)-N6-benzoylsydnonimine (11b). Under an inert atmosphere N3-(o-methoxyphenyl)-N6-benzoylsydnonimine $(0.30 \mathrm{~g}, 1.00 \mathrm{mmol})$ was dissolved in $15 \mathrm{~mL}$ of THF (abs.). Then a $1 \mathrm{M}$ solution of LHMDS in THF $(1.20 \mathrm{~mL}, 1.20 \mathrm{mmol})$ was added and the mixture was cooled to $0{ }^{\circ} \mathrm{C}$. Selenium $(0.10 \mathrm{~g}, 1.20 \mathrm{mmol})$ was added and the mixture was stirred for $0.5 \mathrm{~h}$. Then iodomethane $(0.08 \mathrm{~mL}, 1.20 \mathrm{mmol})$ was added. The mixture was stirred for an additional $0.5 \mathrm{~h}$ at $0{ }^{\circ} \mathrm{C}$, then slowly warmed to $\mathrm{rt}$ and stirred for another $2 \mathrm{~h}$. Afterwards the solvent was evaporated in vacuo. The crude product was purified by column chromatography (DCM:MeOH 40:1). Yield: $0.255 \mathrm{~g}(66 \%)$ of a brownish solid, $\mathrm{mp}: 240^{\circ} \mathrm{C}$ (decomposition); ${ }^{1} \mathrm{H}$ NMR (400 MHz, $\left.\mathrm{CDCl}_{3}\right): \delta=8.32-8.35(\mathrm{~m}, 2 \mathrm{H}, 9 / 9$ '- $\mathrm{H}), 7.64-7.69(\mathrm{~m}, 1 \mathrm{H}$, 15-H), 7.47-7.51 (m, 1H, 11-H), 7.41-7.45 (m, 3H, 10/10'/17-H), 7.17-7.21 (m, $1 \mathrm{H}, 16-\mathrm{H}), 7.15-7.17(\mathrm{~m}, 1 \mathrm{H}, 14-\mathrm{H}), 3.90(\mathrm{~s}, 3 \mathrm{H}, 19-\mathrm{H}), 2.38(\mathrm{~s}, 3 \mathrm{H}, 21-\mathrm{H})$ ppm; ${ }^{13} \mathrm{C}$ NMR $\left(100 \mathrm{MHz}, \mathrm{CDCl}_{3}\right.$ ): $\delta=172.8$ (o, C7), 168.8 (o, C5), 153.3 (o, C13), 137.5 (o, C8), 134.0 (+, C15), 131.3 (+, C11), 129.6 (+, C9/C9'), 127.9 $\left(+, \mathrm{C} 10 / \mathrm{C} 10^{\prime}\right), 127.0(+, \mathrm{C} 17), 122.5$ (o, C12), $121.1(+, \mathrm{C} 16), 112.5(+, \mathrm{C} 14)$, $107.1(+, \mathrm{C} 4), 56.1(+, \mathrm{C} 19), 7.4(+, \mathrm{C} 21) \mathrm{ppm} ;{ }^{77} \mathrm{Se} \mathrm{NMR}\left(114 \mathrm{MHz}, \mathrm{CDCl}_{3}\right)$ : $\delta=106.9$ (s) ppm; IR (ATR): 3056, 2930, 2841, 1553, 1498, 1339, 1311, 1284, $1254,1207,1160,1014,978,753,704,684 \mathrm{~cm}^{-1}$; MS (ESI $\left.30 \mathrm{~V}\right) \mathrm{m} / z(\%)=$ 390.0 (100) $\left[\mathrm{M}+\mathrm{H}^{+}\right], 799.2$ (40) $\left[2 \mathrm{M}+\mathrm{Na}^{+}\right]$; HR-ESI-MS: calcd for $\mathrm{C}_{17} \mathrm{H}_{16} \mathrm{~N}_{3} \mathrm{O}_{3} \mathrm{Se}^{+}$390.0356. Found 390.0357 .

\section{(N3-Morpholinyl-N6-ethoxycarbonyl-sydnonimine-4-yl)-}

(triphenylphosphine)-gold(I) (12a). Under an inert atmosphere Molsidomine $(0.028 \mathrm{~g}, 0.118 \mathrm{mmol}$ ) was dissolved in $10 \mathrm{~mL}$ of THF (abs.). Then a $1 \mathrm{M}$ solution of LHMDS in THF $(0.141 \mathrm{~mL}, 0.141 \mathrm{mmol})$ was added and the mixture was cooled to $-50{ }^{\circ} \mathrm{C}$. After adding chloro(triphenylphosphine)gold(I) $(0.064 \mathrm{~g}, 0.129 \mathrm{mmol})$ the mixture was stirred for $1 \mathrm{~h}$, then slowly warmed to $\mathrm{rt}$ and stirred for another $2 \mathrm{~h}$. Afterwards the solvent was evaporated in vacuo. The crude product was purified by column chromatography (EE:PE 3:1). Yield: $0.041 \mathrm{~g}(50 \%)$ of a colorless solid, mp: $244{ }^{\circ} \mathrm{C}$ (decomposition); ${ }^{1} \mathrm{H}$ NMR $\left(600 \mathrm{MHz}, \mathrm{CDCl}_{3}\right): \delta=7.62-7.66\left(\mathrm{~m}, 3 \times 2 \mathrm{H}, 16 / 16^{\circ}-\mathrm{H}\right), 7.52-7.55(\mathrm{~m}$, $3 \times 1 \mathrm{H}, 18-\mathrm{H}), 7.47-7.50\left(\mathrm{~m}, 3 \times 2 \mathrm{H}, 17 / 17^{\circ}-\mathrm{H}\right), 4.14\left(\mathrm{q}, J_{\mathrm{H}, \mathrm{H}}=7.1 \mathrm{~Hz}, 2 \mathrm{H}, 9-\mathrm{H}\right)$, $3.83\left(\mathrm{t}, J_{\mathrm{H}, \mathrm{H}}=4.5 \mathrm{~Hz}, 4 \mathrm{H}, 13 / 13^{\circ}-\mathrm{H}\right), 4.64\left(\mathrm{t}, J_{\mathrm{H}, \mathrm{H}}=4.5 \mathrm{~Hz}, 4 \mathrm{H}, 12 / 12^{\circ}-\mathrm{H}\right), 1.27$ $\left(\mathrm{t}, J_{\mathrm{H}, \mathrm{H}}=7.1 \mathrm{~Hz}, 3 \mathrm{H}, 10-\mathrm{H}\right) \mathrm{ppm} ;{ }^{13} \mathrm{C} \mathrm{NMR}\left(150 \mathrm{MHz}, \mathrm{CDCl}_{3}\right): \delta=180.8(\mathrm{o}$, d, $\left.{ }^{3} J_{\mathrm{C}, \mathrm{P}}=4.0 \mathrm{~Hz}, \mathrm{C} 5\right), 160.9(\mathrm{o}, \mathrm{C} 7), 145.2\left(\mathrm{o}, \mathrm{d},{ }^{2} J_{\mathrm{C}, \mathrm{P}}=125.5 \mathrm{~Hz}, \mathrm{C} 4\right), 134.3$ $\left(+, \mathrm{d},{ }^{2} J_{\mathrm{C}, \mathrm{P}}=14.0 \mathrm{~Hz}, \mathrm{C} 16 / \mathrm{C} 16^{\circ}\right), 130.6(+, \mathrm{C} 18), 129.8\left(\mathrm{o}, \mathrm{d},{ }^{1} J_{\mathrm{C}, \mathrm{P}}=56.0 \mathrm{~Hz}\right.$, $\mathrm{C} 15), 129.1\left(+, \mathrm{d},{ }^{3} J_{\mathrm{C}, \mathrm{P}}=11.5 \mathrm{~Hz}, \mathrm{C} 17 / \mathrm{C} 17^{\circ}\right), 66.3\left(-, \mathrm{C} 13 / \mathrm{C} 13^{\circ}\right), 60.4(-, \mathrm{C} 9)$, $55.8\left(-, \mathrm{C} 12 / \mathrm{C}^{\circ} 2^{\circ}\right), 14.7(+, \mathrm{C} 10)$ ppm; ${ }^{31} \mathrm{P} \mathrm{NMR}\left(243 \mathrm{MHz}, \mathrm{CDCl}_{3}\right): \delta=40.4$ (s) ppm; IR (ATR): 2972, 2922, 2894, 2855, 1631, 1553, 1435, 1283, 1247, $1193,1100,1062,1039,893,751,692,536,504 \mathrm{~cm}^{-1}$; MS (ESI $\left.10 \mathrm{~V}\right) \mathrm{m} / \mathrm{z}(\%)$ $=701.2(100)[\mathrm{M}+\mathrm{H}+]$; HR-ESI-MS: calcd for $\mathrm{C}_{27} \mathrm{H}_{29} \mathrm{~N}_{4} \mathrm{O}_{4} \mathrm{PAu}^{+} 701.1592$ Found 701.1592

\section{(N3-(o-Methoxyphenyl)-N6-benzoylsydnonimine-4-yl)-}

(triphenylphosphine)-gold(I) (12b). Under an inert atmosphere N3-(omethoxyphenyl)-N6-benzoylsydnonimine $(0.054 \mathrm{~g}, 0.184 \mathrm{mmol})$ was dissolved in $10 \mathrm{~mL}$ of THF (abs.). Then a 1M solution of LHMDS in THF $(0.22 \mathrm{~mL}, 0.221 \mathrm{mmol})$ was added and the mixture was cooled to $-50{ }^{\circ} \mathrm{C}$. After adding chloro(triphenylphosphine)gold(I) $(0.100 \mathrm{~g}, 0.202 \mathrm{mmol})$ the mixture was stirred for $1 \mathrm{~h}$, then slowly warmed to $\mathrm{rt}$ and stirred for another $2 \mathrm{~h}$. Afterwards the solvent was evaporated in vacuo. The crude product is purified by column chromatography (EE:PE $=3: 1)$. Yield: $0.119 \mathrm{~g}(86 \%)$ of a yellow solid, mp: $248{ }^{\circ} \mathrm{C}$ (decomposition); ${ }^{1} \mathrm{H} \mathrm{NMR}\left(600 \mathrm{MHz}, \mathrm{CDCl}_{3}\right): \delta=8.35-8.37$ $\left(\mathrm{m}, 2 \mathrm{H}, 9 / 9^{\circ}-\mathrm{H}\right), 7.57-7.58(\mathrm{~m}, 1 \mathrm{H}, 17-\mathrm{H}), 7.45-7.53(\mathrm{~m}, 3 \times 2 \mathrm{H}+3 \times 1 \mathrm{H}+1 \mathrm{H}$, $\left.21 / 21^{\prime} / 23 / 15-\mathrm{H}\right), 7.34-7.37\left(\mathrm{~m}, 2 \mathrm{H}, 10 / 10^{\circ}-\mathrm{H}\right), 7.38-7.43(\mathrm{~m}, 3 \times 2 \mathrm{H}+2 \mathrm{H}+1 \mathrm{H}$, 22/22 /10/10‘/11-H), 7.04-7.07 (m, 1H, 16-H), 7.00-7.01 (m, 1H, 14-H), 3.70 (s, 3H, 19-H) ppm; ${ }^{13} \mathrm{C} \mathrm{NMR}\left(150 \mathrm{MHz}, \mathrm{CDCl}_{3}\right): \delta=180.0\left(\mathrm{o}, \mathrm{d},{ }^{3} J_{\mathrm{C}, \mathrm{P}}=7.6\right.$ $\mathrm{Hz}, \mathrm{C} 5), 172.0$ (o, C7), 156.0 (o, d, $\left.{ }^{2} J_{\mathrm{C}, \mathrm{P}}=126.5 \mathrm{~Hz}, \mathrm{C} 4\right), 153.8$ (o, C13), 139.4 (o, C8), $134.3\left(+, \mathrm{d},{ }^{2} J_{\mathrm{C}, \mathrm{P}}=14.2 \mathrm{~Hz}, \mathrm{C} 21 / \mathrm{C} 21^{\circ}\right), 132.1(+, \mathrm{C} 15), 131.3(+, \mathrm{C} 23)$, $130.2(+, \mathrm{C} 11), 130.1\left(\mathrm{o}, \mathrm{d},{ }^{1} J_{\mathrm{C}, \mathrm{P}}=55.6 \mathrm{~Hz}, \mathrm{C} 20\right), 129.2\left(+, \mathrm{C} 9 / \mathrm{C} 9{ }^{\circ}\right), 128.9(+$, $\left.\mathrm{d},{ }^{3} J_{\mathrm{C}, \mathrm{P}}=11.3 \mathrm{~Hz}, \mathrm{C} 22 / \mathrm{C} 22^{\circ}\right), 127.9(\mathrm{o}, \mathrm{C} 12), 127.8(+, \mathrm{C} 17), 127.6(+$, $\left.\mathrm{C} 10 / \mathrm{C} 10^{\circ}\right), 120.2(+, \mathrm{C} 16), 112.3(+, \mathrm{C} 14), 55.9(+, \mathrm{C} 19) \mathrm{ppm} ;{ }^{31} \mathrm{P}$ NMR $(243$ $\mathrm{MHz}, \mathrm{CDCl}_{3}$ ): $\delta=40.1$ (s) ppm; IR (ATR): 3051, 3018, 2963, 2839, 1596, 1563, 1498, 1435, 1335, 1282, 1254, 1099, 1022, 847, 746, 709, 690, 675, 536, $500 \mathrm{~cm}^{-1}$; MS (ESI $\left.10 \mathrm{~V}\right) \mathrm{m} / \mathrm{z}(\%)=754.2(100)[\mathrm{M}+\mathrm{H}+]$; HR-ESI-MS: calcd for $\mathrm{C}_{34} \mathrm{H}_{28} \mathrm{~N}_{3} \mathrm{O}_{3} \mathrm{PAu}^{+}$754.1534. Found 754.1533

trans-Chloro-(N3-morpholinyl-N6-ethylester-sydnonimine-4-yl)-bis(triphenylphosphine)-palladium(II) (13a). Under an inert atmosphere Molsidomine $(0.08 \mathrm{~g}, 0.33 \mathrm{mmol})$ was dissolved in $10 \mathrm{~mL}$ of THF (abs.). Then a $1 \mathrm{M}$ solution of LHMDS in THF $(0.40 \mathrm{~mL}, 0.40 \mathrm{mmol})$ was added and the mixture was cooled to $-50 \quad{ }^{\circ} \mathrm{C}$. After adding bis(triphenylphosphine)palladium(II) dichloride $(0.26 \mathrm{~g}, 0.36 \mathrm{mmol})$ the mixture was stirred for $1 \mathrm{~h}$, then slowly warmed to rt and stirred for another 2 h. Afterwards the solvent was evaporated in vacuo. The crude product was purified by column chromatography (1. EE:PE = 3:1, 2. DCM:MeOH = 15:1). Yield: $0.211 \mathrm{~g}(70 \%)$ of a yellow solid, mp: $197{ }^{\circ} \mathrm{C}$ (decomposition); ${ }^{1} \mathrm{H}$ NMR $\left(600 \mathrm{MHz}, \mathrm{CDCl}_{3}\right): \delta=7.62-7.65\left(\mathrm{~m}, 6 \times 2 \mathrm{H}, 15 / 15^{\circ}-\mathrm{H}\right), 7.40-7.43(\mathrm{~m}, 6 \times 1 \mathrm{H}$, 17-H), 7.33-7.36 (m, 6x2H, 16/16'-H), $3.95\left(\mathrm{q}, J_{\mathrm{H}, \mathrm{H}}=7.1 \mathrm{~Hz}, 2 \mathrm{H}, 9-\mathrm{H}\right), 3.69$ $\left(\mathrm{t}, J_{\mathrm{H}, \mathrm{H}}=4.5 \mathrm{~Hz}, 4 \mathrm{H}, 13 / 13^{\circ}-\mathrm{H}\right), 2.76\left(\mathrm{t}, J_{\mathrm{H}, \mathrm{H}}=4.5 \mathrm{~Hz}, 4 \mathrm{H}, 12 / 12^{\circ}-\mathrm{H}\right), 1.18(\mathrm{t}$, $\left.J_{\mathrm{H}, \mathrm{H}}=7.1 \mathrm{~Hz}, 3 \mathrm{H}, 10-\mathrm{H}\right) \mathrm{ppm} .{ }^{13} \mathrm{C} \mathrm{NMR}\left(150 \mathrm{MHz}, \mathrm{CDCl}_{3}\right): \delta=174.8(\mathrm{o}, \mathrm{C} 5)$, 159.5 (o, C7), $134.7\left(+, \mathrm{t},{ }^{2} J_{\mathrm{C}, \mathrm{P}}=6.0 \mathrm{~Hz}, \mathrm{C} 15 / \mathrm{C} 15^{\circ}\right), 130.6(+, \mathrm{C} 17), 130.2(\mathrm{o}$, $\left.\mathrm{t},{ }^{1} J_{\mathrm{C}, \mathrm{P}}=24.0 \mathrm{~Hz}, \mathrm{C} 14\right), 128.0\left(+, \mathrm{t},{ }^{3} J_{\mathrm{C}, \mathrm{P}}=5.3 \mathrm{~Hz}, \mathrm{C} 16 / \mathrm{C} 16^{\circ}\right), 118.0\left(\mathrm{o}, \mathrm{t},{ }^{2} J_{\mathrm{C}, \mathrm{P}}\right.$ $=8.2 \mathrm{~Hz}, \mathrm{C} 4), 65.9\left(-, \mathrm{C} 13 / \mathrm{C} 13^{\circ}\right), 60.2(-, \mathrm{C} 9), 55.1\left(-, \mathrm{C} 12 / \mathrm{C} 12^{\circ}\right), 14.8(+$, C10) ppm. ${ }^{31} \mathrm{P}$ NMR $\left(243 \mathrm{MHz}, \mathrm{CDCl}_{3}\right): \delta=21.0$ (s, trans) ppm; traces of solvent are visible in the spectra. IR (ATR): 3053, 2969, 2859, 1631, 1541, 1481, 1434, 1280, 1237, 1176, 1094, 1061, 1040, 887, 743, 690, $509 \mathrm{~cm}^{-1}$; MS $($ ESI $0 \quad \mathrm{~V}) \mathrm{m} / \mathrm{z}(\%)=907.3(100)\left[\mathrm{M}+\mathrm{H}^{+}\right]$. HR-ESI-MS: calcd for $\mathrm{C}_{45} \mathrm{H}_{44} \mathrm{~N}_{4} \mathrm{O}_{4} \mathrm{P}_{2} \mathrm{PdCl}^{+}$907.1561. Found 907.1559.

trans-Chloro-(N3-(o-methoxyphenyl)-N6-benzoylsydnonimine-4-yl)-bis(triphenylphosphine)-palladium(II) (14b). Under an inert atmosphere N3(o-methoxyphenyl)-N6-benzoylsydnonimine $(0.08 \mathrm{~g}, \quad 0.28 \mathrm{mmol})$ was dissolved in $10 \mathrm{~mL}$ of THF (abs.). Then a 1M solution of LHMDS in THF $(0.33 \mathrm{~mL}, 0.33 \mathrm{mmol})$ was added and the mixture was cooled to $-50{ }^{\circ} \mathrm{C}$. After adding bis(triphenylphosphine)palladium(II) dichloride $(0.21 \mathrm{~g}, 0.31 \mathrm{mmol})$ the mixture was stirred for $1 \mathrm{~h}$, then slowly warmed to $\mathrm{rt}$ and stirred for another $2 \mathrm{~h}$. Afterwards the solvent was evaporated in vacuo. The crude product was purified by column chromatography (EE:PE $=3: 1)$. Yield: $0.143 \mathrm{~g}(54 \%)$ of a yellow solid, mp: $212{ }^{\circ} \mathrm{C}$ (decomposition); ${ }^{1} \mathrm{H}$ NMR $\left(600 \mathrm{MHz}, \mathrm{CDCl}_{3}\right): \delta=$ 8.07-8.09 (m, 2H, 9/9'-H), 7.55-7.52 (m, 1H, 15-H), 7.46-7.49 (m, 6x2H, 21/21'-H), 7.40-7.42 (m, 6x1H+1x2H, 23/11-H), 7.34-7.37 (m, 2H, 10/10'-H), 7.26-7.29 (m, 6x2H, 22/22'-H), 6.98-7.00 (m, 1H, 14-H), 6.75-6.78 (m, 1H, 16-H), 6.24-6.26 (m, 1H, 17-H), $3.13(\mathrm{~s}, 3 \mathrm{H}, 19-\mathrm{H}) \mathrm{ppm} .{ }^{13} \mathrm{C}$ NMR (150 MHz, $\left.\mathrm{CDCl}_{3}\right): \delta=173.2\left(\mathrm{o}, \mathrm{t},{ }^{3} J_{\mathrm{C}, \mathrm{P}}=3.3 \mathrm{~Hz}, \mathrm{C} 5\right), 170.7$ (o, C7), 153.8 (o, C13), 139.5 (o, C8), $134.4\left(+, \mathrm{t},{ }^{2} J_{\mathrm{C}, \mathrm{P}}=6.3 \mathrm{~Hz}, \mathrm{C} 21 / \mathrm{C} 21^{\circ}\right), 132.2(+, \mathrm{C} 15), 130.5(+, \mathrm{C} 23)$, 130.0 (o, t, 1JC,P = 24.5 Hz, C20), $129.8(+, \mathrm{C} 11), 128.6\left(+, \mathrm{C}^{2} \mathrm{C}^{\circ}\right), 128.6$ $\left(\mathrm{o}, \mathrm{t},{ }^{2} J_{\mathrm{C}, \mathrm{P}}=7.8 \mathrm{~Hz}, \mathrm{C} 4\right), 128.4(+, \mathrm{C} 17), 128.2\left(+, \mathrm{t},{ }^{3} J_{\mathrm{C}, \mathrm{P}}=5.0 \mathrm{~Hz}, \mathrm{C} 22 / \mathrm{C} 22^{\circ}\right)$, $127.3\left(+, \mathrm{C} 10 / \mathrm{C} 10^{\circ}\right) 125.8$ (o, C12), $120.2(+, \mathrm{C} 16), 112.4(+, \mathrm{C} 14), 55.5(+$, C19) ppm; ${ }^{31} \mathrm{P}$ NMR $\left(243 \mathrm{MHz}, \mathrm{CDCl}_{3}\right): \delta=20.8$ (s, trans) ppm; traces of solvents are visible in the spectra. IR (ATR): 3052, 2962, 1597, 1537, 1501, $1433,1334,1259,1093,1013,798,744,690,518 \mathrm{~cm}^{-1}$; MS (ESI $\left.0 \mathrm{~V}\right) \mathrm{m} / \mathrm{z}(\%)$

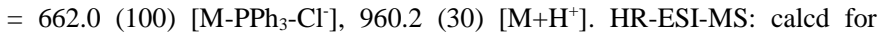
$\mathrm{C}_{52} \mathrm{H}_{43} \mathrm{~N}_{3} \mathrm{O}_{3} \mathrm{P}_{2} \mathrm{PdCl}^{+}$960.1503. Found 960.1503.

\section{General procedure for the preparation of the compounds 14a-c.}

Under a nitrogen atmosphere a sample of 2,5-dibromo-3,4-dinitrothiophene $(0.075 \mathrm{~g}, 0.2 \mathrm{mmol})$ was dissolved in $8 \mathrm{~mL}$ of anhydrous toluene and treated with $10 \mathrm{~mol} \%$ of the catalyst (complexes 13a,b). The mixture was then subjected to ultrasound irradiation for $5 \mathrm{~min}$ and then stirred at room temperature for additional $25 \mathrm{~min}$. Then, two equivalents of the corresponding boronic acid, potassium phosphate $(0.318 \mathrm{~g}, 1.5 \mathrm{mmol})$ and $2 \mathrm{~mL}$ of water were added. The mixture was heated under reflux at $100{ }^{\circ} \mathrm{C}$ for $48 \mathrm{~h}$. After cooling at room temperature, the mixture was dried over magnesium sulfate. The resulting crude products were purified by column chromatography over silica gel using a PE:DCM (1:3) mixture as eluent.

2,5-Diphenyl-3,4-dinitrothiophene (14a). A sample phenylboronic acid $(0.110 \mathrm{~g}, 0.1 \mathrm{mmol})$ was used. The product was isolated as a yellowish solid. Yield $0.057 \mathrm{~g}(77 \%)$ by using complex 13a and $0.046 \mathrm{~g}(62 \%)$ by using complex 13b as the catalyst. ${ }^{1} \mathrm{H}$ NMR $\left(400 \mathrm{MHz}, \mathrm{CDCl}_{3}\right): \delta=7.52-7.60(\mathrm{~m}$, $10 \mathrm{H}) \mathrm{ppm}$. Spectroscopic data are in agreement with those reported in the literature. $^{82}$

2,5-Bis(naphthalen-1-yl)-3,4-dinitrothiophene (14b). A sample 1naphthylboronic acid $(0.102 \mathrm{~g}, 0.1 \mathrm{mmol})$ was used. The product was isolated 
as a yellowish solid. Yield $0.065 \mathrm{~g}(68 \%)$ by using complex 13a and $0.048 \mathrm{~g}$ $(50 \%)$ by using complex $\mathbf{1 3 b}$ as the catalyst. ${ }^{1} \mathrm{H} \mathrm{NMR}\left(400 \mathrm{MHz}, \mathrm{CDCl}_{3}\right): \delta=$ 7.48-7.55 (m, 6H), 7.59-7.61 (d, $\left.J_{\mathrm{H}, \mathrm{H}}=7.8 \mathrm{~Hz}, 2 \mathrm{H}\right), 7.73-7.75(\mathrm{~m}, 2 \mathrm{H}), 7.88$ $7.90(\mathrm{~m}, 2 \mathrm{H}), 7.96-7.98(\mathrm{~d}, \mathrm{~J}=7.8 \mathrm{~Hz}, 2 \mathrm{H}) \mathrm{ppm}$. Spectroscopic data are in agreement with those reported in the literature. ${ }^{45}$

3',4'-Dinitro-2,2':5',2'-terthiophene (14c). A sample 3-thiophenylboronic acid $(0.115 \mathrm{~g}, 0.1 \mathrm{mmol})$ was used. The product was isolated as a yellowish solid. Yield $0.051 \mathrm{~g}(67 \%)$ by using complex 13a and $0.040 \mathrm{~g}(52 \%)$ by using complex $\mathbf{1 3 b}$ as the catalyst. ${ }^{1} \mathrm{H}$ NMR $\left(400 \mathrm{MHz} \mathrm{CDCl}_{3}\right): \delta=7.18(\mathrm{dd}, \mathrm{J}=3.6$, $5.2 \mathrm{~Hz}, 2 \mathrm{H}), 7.55\left(\mathrm{dd}, J_{\mathrm{H}, \mathrm{H}}=1.2,3.6 \mathrm{~Hz}, 2 \mathrm{H}\right), 7.61\left(\mathrm{dd}, J_{\mathrm{H}, \mathrm{H}}=1.2,5.2 \mathrm{~Hz}, 2 \mathrm{H}\right)$ ppm. Spectroscopic data are in agreement with those reported in the literature. ${ }^{45}$

\section{General procedure for the preparation of the compounds 15a-c.}

Under a nitrogen atmosphere $2.5 \mathrm{mmol}$ of the arylhalogenides were dissolved in $15 \mathrm{~mL}$ of anhydrous triethylamine and treated with $1 \mathrm{~mol} \%$ of the catalyst (complexes 13a,b) and copper-(I)-iodide $(0.015 \mathrm{~g}, 0.07 \mathrm{mmol})$. After the addition of the catalysts, 1.2 eq of 2-methyl-3-butyn-2-ol $(0.25 \mathrm{~g}, 3 \mathrm{mmol})$ were slowly added dropwise. Then the reaction mixture was stirred under reflux for $48 \mathrm{~h}$. After cooling down at room temperature, water was added. The mixture was extracted with dichloromethane and dried over magnesium sulfate. The resulting crude products were purified by column chromatography over silica gel (40-60 mesh) using PE:EE (2:1) mixture as eluent.

2-Methyl-4-phenylbut-3-yn-2-ol (15a). A sample of bromobenzene $(0.393 \mathrm{~g}$, $2.5 \mathrm{mmol}$ ) was used. The product was isolated as a brown solid. Yield $0.414 \mathrm{~g}$ $(87 \%)$ by using complex 13a and $0.395 \mathrm{~g}(83 \%)$ by using complex 13b as the catalyst. ${ }^{1} \mathrm{H}$ NMR $\left(400 \mathrm{MHz}, \mathrm{CDCl}_{3}\right): \delta=1.62(\mathrm{~s}, 6 \mathrm{H}), 1.99(\mathrm{~s}, 1 \mathrm{H}, \mathrm{OH}), 7.29$ $7.32(\mathrm{~m}, 3 \mathrm{H}), 7.40-7.43(\mathrm{~m}, 1 \mathrm{H}) \mathrm{ppm}$. Spectroscopic data are in agreement with those reported in the literature. ${ }^{83}$

2-Methyl-4-(naphthylen-1-yl)but-3-yn-2-ol (15b). A sample of 1bromonaphthalene $(0.517 \mathrm{~g}, 2.5 \mathrm{mmol})$ was used. The product was isolated as a brown solid. Yield of $0.393 \mathrm{~g}(63 \%)$ by using complex 13a and $0.318 \mathrm{~g}(51 \%)$ by using complex $\mathbf{1 3 b}$ as the catalyst. ${ }^{1} \mathrm{H}$ NMR (400 $\left.\mathrm{MHz}, \mathrm{CDCl}_{3}\right): \delta=1.71$ $(\mathrm{s}, 6 \mathrm{H}), 2.72(\mathrm{~s}, 1 \mathrm{H}, \mathrm{OH}), 7.33-7.36(\mathrm{~m}, 1 \mathrm{H}), 7.44-7.48(\mathrm{~m}, 1 \mathrm{H}), 7.52-7.55(\mathrm{~m}$, $1 \mathrm{H}), 7.60(\mathrm{~d}, \mathrm{~J}=7.8 \mathrm{~Hz}, 1 \mathrm{H}), 7.74-7.80(\mathrm{~m}, 2 \mathrm{H}), 8.28(\mathrm{~d}, \mathrm{~J}=7.8 \mathrm{~Hz}, 1 \mathrm{H}) \mathrm{ppm}$. Spectroscopic data are in agreement with those reported in the literature. ${ }^{84}$

2-Methyl-4-(thiophen-3-yl)but-3-yn-2-ol (15c). A sample of of 3bromothiophene $(0.408 \mathrm{~g}, 2.5 \mathrm{mmol})$ was used. The product was isolated as a brown solid. Yield $0.385 \mathrm{~g}(78 \%)$ by using complex 13a and $0.341 \mathrm{~g}(69 \%)$ by using complex 13b as the catalyst. ${ }^{1} \mathrm{H}$ NMR (400 MHz, $\mathrm{CDCl}_{3}$ ): $\delta=1.53$ (s, $6 \mathrm{H}), 2.19(\mathrm{~s}, 1 \mathrm{H}, \mathrm{OH}), 7.01\left(\mathrm{~d}, J_{\mathrm{H}, \mathrm{H}}=7.8 \mathrm{~Hz}, 1 \mathrm{H}\right), 7.15-7.18(\mathrm{~m}, 1 \mathrm{H}), 7.33(\mathrm{~d}$, $\left.J_{\mathrm{H}, \mathrm{H}}=7.8 \mathrm{~Hz}, 1 \mathrm{H}\right) \mathrm{ppm}$. Spectroscopic data are in agreement with those reported in the literature. ${ }^{85}$

\section{References}

1. Review: A. Nasr, A. Winkler, M. Tamm, Coord. Chem. Rev. 2016, 316 , $68-124$.

2. Review: J. B. Waters, J. M. Goicoechea, Coord. Chem. Rev. 2015, 293, 80 $-94$

3. Y. Wang, M. Y. Abraham, R. J. Gilliard, P. Wei, J. C. Smith, G. H Robinson, Organometallics 2012, 31, $791-793$.

4. Y. Wang, Y. Xie, M. Y. Abraham, P. Wei, H. F. Schaefer, P. v. R. Schleyer, G. H. Robinson, Organometallics 2011, 30, 1303 - 1306.

5. Y. Wang, Y. Xie, M. Y. Abraham, P. Wei, H. F. Schaefer, P. v. R Schleyer, G. H. Robinson, J. Am. Chem. Soc. 2010, 132, 14370-14372.

6. N. Vujkovic, V. César, N. Lugan, G. Lavigne, Chem. Eur. J. 2011, 17, $13151-13155$.

7. X. Yan, J. Bouffard, G. Guisado-Barrios, B. Donnadieu, G. Bertrand, Chem. Eur. J. 2012, 18, 14627 - 14631.

8. A. Jana, R. Azhakar, G. Tavčar, H. W. Roesky, I. Objartel, D. Stalke, Eur. J. Inorg. Chem. 2011, 3686 - 3689.

9. A. Solovyev, E. Lacôte, D. P. Curran, Org. Lett. 2011, 13, $6042-6045$.

10. K. E. Krahulic, H. M. Tuononen, M. Parvez, R. Roesler, J. Am. Chem. Soc. 2009, 131, 5858 - 5865 .

11. L. Benhamou, N. Vujkovic, V. César, H. Gornitzka, N. L. Lugan, G. Lavigne, Organometallics 2010, 29, 2616 - 2630.

12. E. L. Kolychev, S. Kronig, K. Brandhorst, M. Freytag, P. G. Jones, M. Tamm, J. Am. Chem. Soc. 2013, 135, 12448 - 12459.

13. S. Kronig, E. Theuergarten, C. G. Daniliuc, P. G. Jones, M. Tamm, Angew. Chem. 2012, 124, 3294 - 3298; Angew. Chem. Int. Ed. 2012, 51, 3240 3244.

14. A. A. Danopoulos, K. Y. Monakhov, P. Braunstein, Chem. Eur. J. 2013, $19,450-455$
15. P. K. Majhi, G. Schnakenburg, Z. Kelemen, L. Nyulaszi, D. P. Gates, R. Streubel, Angew. Chem. 2013, 125, 10264 - 10267; Angew. Chem. Int. Ed. 2013, 52, 10080 - 10083 .

16. J. B. Waters, R. S. P. Turbervill, J. M. Goicoechea, Organometallics 2013 , $32,5190-5200$.

17. R. A. Musgrave, R. S. P. Turbervill, M. Irwin, J. M. Goicoechea, Angew. Chem. 2012, 124, 10990 - 10993; Angew. Chem. Int. Ed. 2012, 51, 10832 $-10835$

18. P. L. Arnold, S. T. Liddle, Organometallics 2006, 25, 1485 - 1491.

19. A. Ferry, K. Schaepe, P. Tegeder, C. Richter, K. M. Chepiga, B. J. Ravoo, F. Glorius, ACS Catal. 2015, 5, 5414 - 5420.

20. V. César, V. Mallardo, A. Nano, G. Dahm, N. Lugan, G. Lavigne, S. Bellemin-Laponnaz, Chem. Commun. 2015, 51, 5271 - 5274.

21. N. Pidlypnyi, S. Wolf, M. Liu, K. Rissanen, M. Nieger, A. Schmidt, Tetrahedron 2014, 70, 8672 - 8680.

22. N. Pidlypnyi, F. Uhrner, M. Nieger, M. H. H. Drafz, E. G. Hübner, J. C. Namyslo, A. Schmidt, Eur. J. Org. Chem. 2013, 7739 - 7748.

23. N. Pidlypnyi, J. C. Namyslo, M. H. H. Drafz, M. Nieger, A. Schmidt, J. Org. Chem. 2013, 78, $1070-1078$.

24. M. Liu, J. C. Namyslo, M. Nieger, M. Polamo, A. Schmidt, Beilstein J. Org. Chem. 2016, 12, 2673 - 2681.

25. M. Liu, M. Nieger, E. Hübner, A. Schmidt, Chem. Eur. J. 2016, 5416 5424.

26. J. Zhang, M. Franz, E. Hübner, A. Schmidt, Tetrahedron 2016, 72, 525 531 .

27. M. Liu, M. Nieger, A. Schmidt, Chem. Commun. 2015, 51, 477 - 479.

28. V. César, J.-C. Tourneux, N. Vujkovic, R. Brousses, N. Lugan, G. Lavigne, Chem. Commun. 2012, 48, 2349 - 2351.

29. L. Benhamou, N. Vujkovic, V. César, H. Gornitzka, N. Lugan, G. Lavigne, Organometallics 2010, 29, 2616 - 2630.

30. L. Benhamou, V. César, H. Gornitzka, N. Lugan, G. Lavigne, Chem. Commun. 2009, $4720-4722$

31. A. T. Biju, K. Hirano, R. Fröhlich, F. Glorius, Chem. Asian J. 2009, 4, $1786-1789$

32. A. A. Danopoulos, K. Yu. Monakhov, P. Braunstein, Chem. Eur. J. 2013, $19,450-455$.

33. C. A. Ramsden, Tetrahedron 2013, 69, 4146 - 4159.

34. C. A. Ramsden, W. P. Oziminski, Tetrahedron 2014, 70, 7158 - 7165.

35. C. A. Ramsden, Progress in Heterocyclic Chem. 2016, 28, 1 - 25.

36. V. César, L. C. Misal Castro, T. Dombray, J.-B. Sortais, C. Darcel, S. Labat, K. Miqueu, J.-M. Sotiropoulos, R. Brousses, N. Lugan, G. Lavigne, Organometallics 2013, 32, 4643 - 4655.

37. V. César, N. L. Lugan, G. Lavigne, J. Am. Chem. Soc. 2008, 130, 11286 11287

38. V. César, S. Labat, K. Miqueu, J.-M. Sotiropoulos, R. Brousses, N. Lugan, G. Lavigne, Chem. Eur. J. 2013, 19, 17113 - 17124.

39. M. G. Hobbs, C. J. Knapp, P. T. Welsh, J. Borau-Garcia, T. Ziegler, R. Roesler, Chem. Eur. J. 2010, 16, 14520 - 14533

40. A. Schmidt, S. Wiechmann, T. Freese, ARKIVOC 2013, i, 424 - 469.

41. P. Ai, A. A. Danopoulos, P. Braunstein, Inorg. Chem. 2015, 54, 3722 3724.

42. C. Pranckevicius, D. W. Stephan, Chem. Eur. J. 2014, 6597 - 6602.

43. A. Igarashi, E. L. Kolychev, M. Tamm, K. Nomura, Organometallics 2016, $1778-1784$

44. A. Winkler, K. Brandhorst, M. Freytag, P. G. Jones, M. Tamm, Organometallics 2016, 1160 - 1169.

45. S. Wiechmann, T. Freese, M. H. H. Drafz, E. G. Hübner, J. C. Namyslo, M. Nieger, A. Schmidt, Chem. Commun. 2014, 50, 11822 - 11824.

46. A.-L. Lücke, S. Wiechmann, T. Freese, Z. Guan, A. Schmidt, Z. Naturforsch. 2016, 71b, 643 - 650.

47. J. Scholtholt, Handbook of Experimental Pharmacology 1985, 76, 365

48. Y. Shang, D. Wang, R. Li, C. J. Huang, Cardiovasc. Pharmacol. 2016, 68, $342-355$.

49. T. Kalouda, N. Pitsikas, Pharm. Biochem. Behav. 2015, 138, 111 - 116.

50. O. M. Disli, E. Sarihan, M. C. Colak, N. Vardi, A. Polat, J. Yagmur, B. Tamtekin, H. Parlakpinar, Eur. Surg. Res. 2013, 51, 79 - 90.

51. M. Marvasi, I. A. Durie, E. S. McLamore, D. C. Vanegas, P.Chaturvedi, $A M B$ Express 2015, 5, 28

52. P. Zordan, C. Sciorati, L. Campana, L. Cottone, E. Clementi, P.-R. Querini, S. Brunelli, Eur. J. Pharmacol. 2013, 715, 296 - 303.

53. T. L. Gilchrist in Science of Synthesis, Vol. 13 (Eds.: Storr, R. C., Gilchrist, T. L.), Thieme Verlag, Stuttgart, 2004, p. 109

54. H. Meier, N. Hanold, in Houben-Weyl, Methoden der organischen Chemie, Vol. E 8c (Eds.: K. H. Büchel, J. Falbe, H. Hagemann, M. Hanack, D. Klamann, R. Kreher, H. Kropf, M. Regitz, E. Schaumann), Thieme Verlag, Stuttgart, 1994, p. 403.

55. P. Brookes, J. Walker, J. Chem. Soc. 1957, 4409 - 4416.

56. H. Kato, M. Hashimoto, M. Ohta, Nippon Kagaku Zasshi 1957, 78, 707. 
57. Review about sydnone imines: V. G. Yashunskii, L. E. Kholodov, Russ. Chem. Rev. 1980, 49, 28 - 45.

58 W. D. Ollis, C. A. Ramsden, Adv. Heterocycl. Chem. 1976, 19, 1 - 122.

59. W. D. Ollis, S. P. Stanforth, C. A. Ramsden, Tetrahedron 1985, 41, 2239 $-2329$.

60. Review: A. Schmidt, S. Wiechmann, C. F. Otto, Adv. Heterocycl. Chem. 2016, $119,143-172$.

61. A. Schmidt, S. Batsyts, A. Smeyanov, T. Freese, E. G. Hübner, M. Nieger, J. Org. Chem. 2016, 81, $4202-4209$.

62. A. Schmidt, M. K. Kindermann, J. Org. Chem. 1997, 62, 3910 - 3918.

63. Y. Koto, F. Shibahara, T. Murai, Org. Biomol. Chem. 2017, 15, 1810 1820.

64. A. Nortcliffe, N. P. Botting, D. O'Hagan, Org. Biomol. Chem. 2013, 11, 4657.

65. H. U. Daeniker, J. Druey, Helv. Chim. Acta 1962, 45, 2426 - 2441.

66. L. E. Kholodov, A. M. Khelem, V. G. Yashunskii, Zh. Org. Khim. 1967, 3,1870 .

67. A. Chinone, M. Ohta, Chem. Lett. 1972, 969 - 970.

68. H. U. Daeniker, J. Druey, Helv. Chim. Acta 1962, 45, 2441 - 2461.

69. Y. Saito, T. Teraji, T. Kamiya, Tetrahedron Lett. 1971, 2893 - 2896

70. V. N. Kalinin, S. N. Lebedev, I. A. Cherepanov, I. A. Godovikov, K. A. Lyssenko, E. Hey-Hawkins, Polyhedron 2009, 28, 2411 - 2417.

71. I. A. Cherepanov, N. V. Egorova, K. B. Martinovich, V. N. Kalinin, Doklady Chem. 2000, 374, 175.

72. I. A. Cherepanov, V. N. Kalinin, Mendeleev Commun. 2000, 181 - 182.

73. T. T. Dang, N. Rasool, T. T. Dang, H. Reinke, P. Langer, Tetrahedron Lett. 2007, 48, 845 - 847.

74. C. P. Sen, R. G. Shrestha, L. K. Shrestha, K. Ariga, S. Valiyaveettil, Chem. Eur. J. 2015, 21, 17344 - 17354.

75. M. K. Hussain, M. I. Ansari, R. Kant, K. Hajela, Org. Lett. 2014, 16, 560 $-563$.

76. M. T. Rahman, T. Fukuyama, I. Ryu, K. Suzuki, K. Yonemura, P. F. Hughes, K. Nokihara, Tetrahedron Lett. 2006, 47, 2703 - 2706.

77. C. Torborg, J. Huang, T. Schulz, B. Schäffner, A. Zapf, A. Spannenberg, A. Börner, M. Beller, Chem. Eur. J. 2009, 15, 1329 - 1336.

78. Review: D. L. Browne, J. P. Harrity, Tetrahedron 2010, 66, 553 - 568.

79. G. M. Sheldrick, Acta Crystallogr. 2008, A64, 112-122.

80. G. M. Sheldrick, Acta Crystallogr. 2015, C71, 3-8.

81. V. Zoete, F. Bailly, J.-P. Catteau, J.-L. Bernie, J. Chem. Soc., Perkin Trans. 1 1997, $2983-2988$

82. Q. Li, J. Li, L. Deng, Q. Wang, Z. Gao, D. Liu, Chem. Lett. 2011, 40, 417 $-418$.

83. S. Fu, N.-Y. Chen, X. Liu, Z. Shao, S.-P. Luo, Q. Liu, J. Am. Chem. Soc. 2016, 138, $8588-8594$.

84. J. Jin, Y. Luo, C. Zhou, X. Chen, Q. Wen, P. Lu, Y. Wang, J. Org. Chem. 2012, 77, $11368-11373$

85. E. Paegle, P. Balyakov, P. Asenyan, Eur. J. Org. Chem. 2014, 3831 - 3840. 